Check for updates

Cite this: RSC Adv., 2018, 8, 24444

\title{
Pyrrolidine and oxazolidine ring transformations in proline and serine derivatives of $\alpha$ - hydroxyphosphonates induced by deoxyfluorinating reagents $\uparrow$
}

\begin{abstract}
Patrycja Kaczmarek, Magdalena Rapp iD * and Henryk Koroniak
Transformations of $\alpha$-hydroxyphosphonates derived from proline or serine by treatment with different deoxyfluorinating reagents (DAST, Deoxofluor, PyFluor) are reported. Depending on the applied reagent, as well as the protecting group used $(\mathrm{N}-\mathrm{Cbz}, \mathrm{N}-\mathrm{Boc}, \mathrm{N}-\mathrm{Bn})$ different types of products are observed. The reaction of $\mathrm{N}-\mathrm{Cbz}$ or $\mathrm{N}$-Boc prolinols with DAST or Deoxofluor due to aziridinium intermediate participation gave fluorinated amino phosphonates such as piperidine and pyrrolidine derivatives and/or oxazolidine-2-ones. Similarly, the analogous reaction of $\mathrm{N}$ - $\mathrm{Cbz}$ or $\mathrm{N}$-Boc protected serinol yielded oxazolidine-2-ones or its fluorinated analogues. As the second type of product formed by DASTinduced reaction of serine derivatives, aziridines were obtained. Only in the case of deoxyfluorination of $N$-benzyl prolinols were both diastereoisomers of $\beta$-fluoropiperidine- $\alpha$-phosphonates formed, while the reaction of protected $\mathrm{N}$-benzyl serinols gave fluorinated oxazolidines. Moreover, application of PyFluor gave sulfonate derivatives.
\end{abstract}

Received 16th June 2018

Accepted 30th June 2018

DOI: $10.1039 / c 8 r a 05186 k$

rsc.li/rsc-advances reported. ${ }^{7}$ Moreover, since the observation, that group of $\alpha$ monofluoroalkylaminophosphonates could be applied as a nonhydrolysable isopolar surrogate of naturally occurring phosphates (where $\mathrm{C}-\mathrm{O}-\mathrm{P}$ bridge was replaced by $\mathrm{C}-\mathrm{CHF}-\mathrm{P}$ linkages $),{ }^{8}$ several syntheses of some monofluorinated alkylphosphonic acid analogues have been reported. ${ }^{9}$ The introduction of the fluorine atom in organic compounds has a deep electronic and steric impact, affecting interactions between fluorine-containing inhibitors and target enzymes. ${ }^{\mathbf{1 0}}$ This effect is especially noticeable in a group of fluorinated amino phosphonates. ${ }^{\mathbf{1 1}}$ Thus, monofluoro- and difluoro phosphoserine analogues as potent inhibitors of alanine racemase have been reported. ${ }^{\mathbf{1 1 a}}$ Moreover, dipeptides containing $\beta$ fluorinated phosphoproline have been designed as a phosphonate-based transition-state analogue of inhibitors of proline selective serine dipeptidases. ${ }^{11 b}$

One of the common strategy in the synthesis of monofluorinated amino phosphonates has involved nucleophilic fluorination of the hydroxyl group in hydroxyphosphonates and as the most common reagents (diethylamino)sulfur trifluoride (DAST), ${ }^{12}$ DeoxoFluor ${ }^{13}$ and PyFluor ${ }^{14}$ were used. Generally, the mechanism of deoxyfluorination with DAST involves the attack of the hydroxyl group of alcohol substrate to the electrophilic deoxyfluorinating agent (with a generation of activated alcohol $-\mathrm{OSF}_{2} \mathrm{NEt}_{2}$ along with fluoride ion).

The latter then displaces of leaving group to produce the corresponding alkyl fluoride. However, $\beta$-aminoalcohols such as prolinol derivatives the reaction is frequently going through 


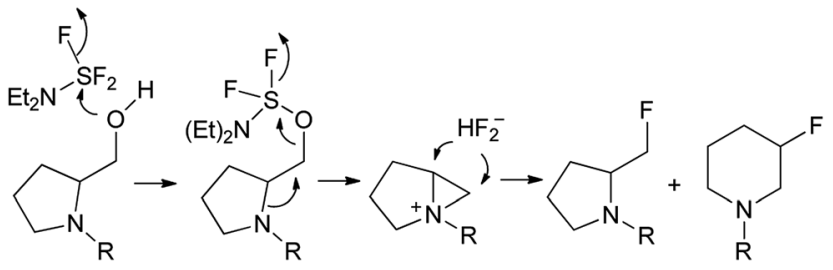

Scheme 1 Deoxyfluorination of prolinol with DAST.

aziridinium intermediate due to neighbouring group participation leading to ring opening by fluoride ion, resulting in restoration or ring expansion in some cases (Scheme 1). ${ }^{.5}$ In case of phosphonates, depending on the structure and applied reagent, the fluorination proceeds with different regioselectivity. Thus, fluorination with DAST of $\alpha$-hydroxy- $\beta$-aminoalkylphosphonates originated from aliphatic amino acids as well as phenylalanine gave $\beta$-fluoro- $\alpha$-aminoalkylphosphonates as major isomers. ${ }^{16}$ For comparison, the application of PyFluor and DBU in the same systems resulted in the formation of mainly $\alpha$-fluoro- $\beta$-aminoalkylphosphonates. ${ }^{17}$ On the other hand, the reactions of proline derived $\alpha$-hydroxyphosphonates with DAST led to the corresponding $\alpha$-fluoroalkylphosphonates ${ }^{11 b}$ while the fluorination of $\beta$-hydroxy- $\gamma$ aminoalkylphosphonates gave the appropriate $\beta$-fluoroalkylphosphonates. ${ }^{11 c}$ Other approaches yielding $\alpha$-fluoro- $\beta$ aminoalkylphosphonates involved electrophilic fluorination of $\beta$-ketophosphonates and next enamine formation ${ }^{18}$ or addition of anion species $\left[\mathrm{C}(\mathrm{TMS}) \mathrm{FP}(\mathrm{O})(\mathrm{OEt})_{2}\right]^{-}$to appropriate iminium salt. $^{8 a}$ Moreover, applications of suitable methylphosphonate carbanions in the synthesis of $\alpha$-fluoro- $\gamma$-amino phosphonates $^{11 c, 19}$ or $\gamma$-monofluoro- $\beta$-aminoalkylphosphonates ${ }^{20}$ were reported.

Our recent studies revealed that nucleophilic fluorination of $\alpha$ hydroxyphosphonates derived from $O$-isopropylidene glyceraldehyde with DAST has led to oxirane formation due to the substitution of DAST-derived leaving group by hydroxyl group from the adjacent stereogenic centre. ${ }^{21}$ By contrast, stereoselective deoxyfluorination of hydroxyphosphonates derived from an $O$-isopropylidenepentofuranose gave major fluoride possessing $\mathrm{D}-\mathrm{g} l u$ configuration. Moreover, we found that fluorination of tertiary alcohols derived from di-O-isopropylidenehexofuranose and 1,2-Oisopropylidenepentofuranose have been stereo controlled by the neighbouring bottom-face 1,2-O-isopropylidene group oxygen atom leading preferentially to one diastereoisomer of allylic, phenylacetylene, styryl, and benzylic fluorides. ${ }^{22}$ Herein, we present our studies evaluating different substrates scope for deoxyfluorination reaction with an emphasis on neighbouring group participation resulting transformation of phosphonate amino acids analogues.

\section{Results and discussion}

We started with $\alpha$-hydroxyphosphonates derivatives of proline and serine possessing $\mathrm{N}$-carboxybenzyl, $\mathrm{N}$-tert-butoxycarbonyl, and $N$-benzyl as protecting groups. Thus the nucleophilic fluorination of prolinols such as $\mathbf{1 a}, \mathbf{b}(\mathrm{Cbz}), \mathbf{2 a}, \mathbf{b}(\mathrm{Boc})$ and $\mathbf{3 a}, \mathbf{b}(\mathrm{Bn})$

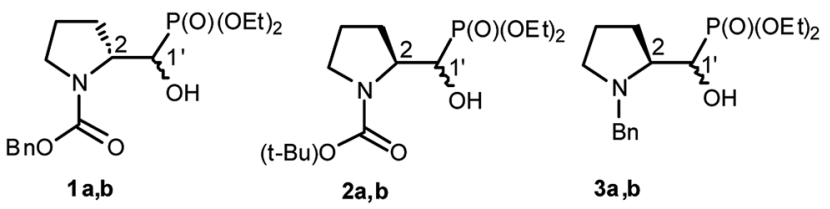

Scheme 2 Structures of starting $\alpha$-hydroxyphosphonates proline derivatives $1-3 a, b$.

prepared according to known procedures (see Experimental section) were performed. Predominantly diastereoisomers $\left(2 R, 1^{\prime} S\right)-\mathbf{1 a}$ and $\left(2 S, 1^{\prime} R\right)-\mathbf{2 a}, \mathbf{3 a}$ were applied, while minor diastereoisomers possess $\left(2 R, 1^{\prime} R\right)-\mathbf{1 b}$ and $\left(2 S, 1^{\prime} S\right)-\mathbf{2 b}, \mathbf{3 b}$ configurations, respectively (Scheme 2). Treatment of $\alpha$ hydroxyphosphonates 1a,b or $\mathbf{2 a , b}$ with DAST gave mainly two type of phosphonates 4-7 ( ${ }^{31} \mathrm{P}$ NMR)(Scheme 3$)$.

Primary experiments indicated that compounds 4 and 5 , as well as non-fluorinated $6 \mathbf{a}$ or $7 \mathbf{a}$, arose from major $1 \mathbf{a}\left(2 R, 1^{\prime} S\right)$ or 2a $\left(2 S, 1^{\prime} R\right)$ diastereoisomers while from $\mathbf{1 b}\left(2 R, 1^{\prime} R\right)$ or $\mathbf{2 b}$ $\left(2 S, 1^{\prime} S\right)$ only bicyclic $\mathbf{6 b}$ or $7 \mathbf{b}$ were formed (Table 1$)$. Stereochemistry of the fluorination of 1a (or 2a) is a consequence of the transformation of $\alpha$-hydroxyl moiety into good leaving group $\left(-\mathrm{OSF}_{2} \mathrm{~N}(\mathrm{Et})_{2}\right)$ and its substitution by electron pair of pyrrolidine nitrogen atom $\left(\mathrm{S}_{\mathrm{N}} 2\right.$, pathway a Scheme 3) yielding aziridinium ion, analogously to the intermediate formed during fluorination of proline derivatives (Scheme 1). A subsequent attack of fluoride ion as $\mathrm{HF}_{2}{ }^{-}$(second $\mathrm{S}_{\mathrm{N}} 2$ reaction) gave preferentially $\beta$-fluoro- $\alpha$-phosphonate piperidine 4 or 5 . Ring expansion during deoxyfluorination of prolinols with DAST has been already reported..$^{15}$ Moreover, rearrangement of optically active prolinols by treatment with DAST afforded only one optically active diastereoisomer of piperidines. ${ }^{15}$ Also, Kaźmierczak et al. reported fluorination of $\alpha$-hydroxyphosphonate analogues of amino acids such as phenylalanine or valine leading to $\alpha$-amino- $\beta$-fluoroalkylphosphonates via aziridinium ion. ${ }^{16}$ In our case, two signals of main fluorinated product 4 or 5 [appearing as a mixture of rotamers $(1.1: 1$, r.r.),

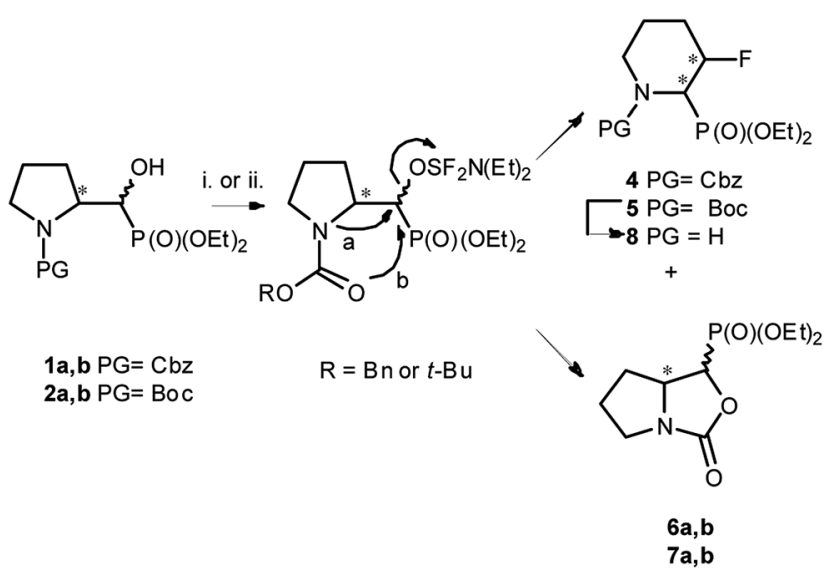

Scheme 3 Reaction of 1-2a,b with DAST (Table 1) (4 43\% and 6a,b $45 \% ; 538 \%$ and $7 \mathrm{a}, \mathrm{b} 53 \%)$; or DeoxoFluor $\left(\mathrm{CH}_{2} \mathrm{Cl}_{2}, \mathrm{RT}, 24 \mathrm{~h}\right)(438 \%$ and $6 \mathrm{a}, \mathrm{b} 43 \% ; 530 \%$ and $7 \mathrm{a}, \mathrm{b} 48 \%$ ); and deprotection of 5 (8 73\%); [configurations of stereogenic centres in the text]. 
Table 1 Fluorination of $1 \mathrm{a}, \mathrm{b}$ or $2 \mathrm{a}, \mathrm{b}$ with different fluorinating agents ${ }^{a}$

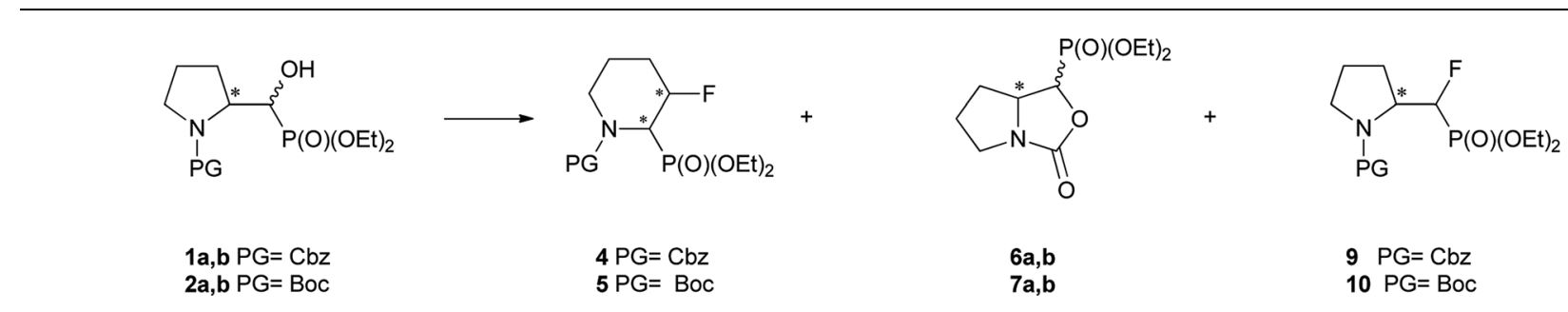

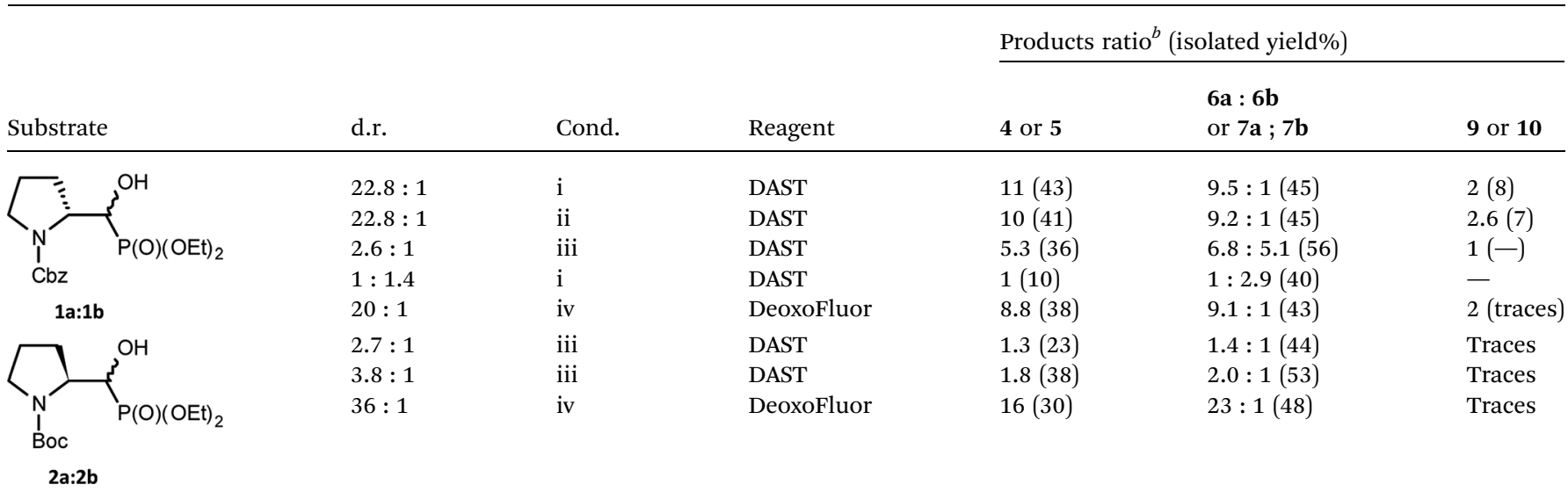

${ }^{a}(\mathrm{i})-78{ }^{\circ} \mathrm{C} \rightarrow 0{ }^{\circ} \mathrm{C}(1.5 \mathrm{~h})$; (ii) $0{ }^{\circ} \mathrm{C} \rightarrow 40{ }^{\circ} \mathrm{C}(1 \mathrm{~h})$; (iii) $-78{ }^{\circ} \mathrm{C}, 3 \mathrm{~h}, \mathrm{RT}(1 \mathrm{~h})$; (iv) RT $(24 \mathrm{~h}) .{ }^{b}$ Ratio of products in crude reaction mixture, ${ }^{31} \mathrm{P}$ NMR.

due to presence of $\mathrm{N}$-Cbz or $\mathrm{N}$-Boc protecting group, isolated yields $43 \%$ and $38 \%$, respectively] were located in ${ }^{19} \mathrm{~F}$ NMR at $\delta$ : $-180 / 179 \mathrm{ppm}$ (as $\mathrm{m}$ ), in the area habitually occupied by signal of secondary alkyl fluoride. ${ }^{23}$ Moreover, coupling constants values ${ }^{2} J_{\mathrm{H} 2 \mathrm{P}} 21 \mathrm{~Hz},{ }^{2} J_{\mathrm{H} 3 \mathrm{~F}} 46 \mathrm{~Hz},{ }^{3} J_{\mathrm{H} 2 \mathrm{~F}} 19 \mathrm{~Hz}$ as well as the location of signals for $C \mathrm{HF}$ at $\delta: 85 \mathrm{ppm}\left({ }^{2} J_{\mathrm{CF}} 179 \mathrm{~Hz}\right), C \mathrm{HP}$ at c.a. $\delta$ : $53 \mathrm{ppm}\left({ }^{2} J_{\mathrm{CP}} 150 \mathrm{~Hz},{ }^{3} J_{\mathrm{CF}} 22 \mathrm{~Hz}\right)$ in ${ }^{13} \mathrm{C}$ NMR spectra indicated piperidine ring formation with the vicinal arrangement of fluorine substituent and phosphonate moiety. To compare, in case of fluorocyclohexane the values of coupling constants ${ }^{3} J_{\mathrm{HF}}$ equal $44 \mathrm{~Hz}$ (for anti) or ${ }^{3} J_{\mathrm{HF}} 10 \mathrm{~Hz}$ for gauche conformations were reported. ${ }^{23}$ In our case, we have observed the extremely high value of coupling constants $\left({ }^{3} J_{\mathrm{FP}} 62 / 63 \mathrm{~Hz}\right)$. Usually, the ${ }^{3} J_{\mathrm{PF}}$ coupling constants range from $c$.a. $0 \mathrm{~Hz}$ to $9 \mathrm{~Hz}$ as observed for two stereoisomers of diethyl 2-fluorocyclohexyl phosphonate. ${ }^{24}$ On the other hand, in case of $N, N$-dibenzyl- $\alpha$-amino- $\beta$ fluoroalkylphosphonates the values of $J$ for conformations gauche $\left({ }^{3} J_{\mathrm{PF}} 8-10 \mathrm{~Hz}\right)$ and anti $\left({ }^{3} J_{\mathrm{PF}} 15-19 \mathrm{~Hz}\right)$ were reported. ${ }^{16} \mathrm{In}$ our case the most probably, the high value of coupling constants is due to the attempted arrangement of $\mathrm{C}-\mathrm{F}$ and $\mathrm{C}-\mathrm{P}$ bonds with equatorially situated fluorine and phosphonate substituents $^{25}$ in the ring. Thus, piperidine existed as slightly twisted boat conformation forced the most probably by bulky $N$ protecting group vicinal to phosphonate moiety (compound $\mathbf{4}$, Scheme 4). Stereochemistry of $\mathbf{4}$ as $(2 R, 3 R)$ was confirmed by further ${ }^{19} \mathrm{~F}-{ }^{1} \mathrm{H}$ HOESY experiments showing NOEs between fluorine atom and protons: $\mathrm{H}-4$ and $\mathrm{H}-5$; as well as NOEs between $\mathrm{H}-2$ (CHP) and $\mathrm{H}-3(\mathrm{CHF})\left({ }^{1} \mathrm{H}^{-1} \mathrm{H}\right.$ NOESY) and indicated the additional participation of protecting group ( $N$-Boc) in

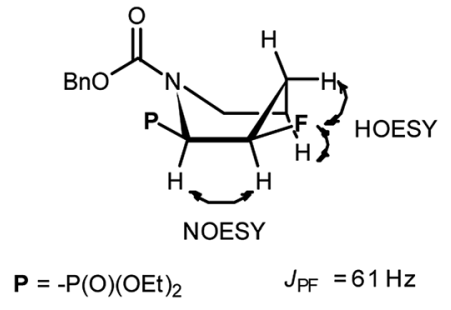

Scheme 4 The slightly twisted boat conformation of 4 with observed correlations and values of coupling constants.

product formation. Also in $\beta$-fluoroethylamide $\mathrm{C}-\mathrm{F}$ and $\mathrm{CN}(\mathrm{CO})$ bonds prefer to adopt the gauche conformation. ${ }^{26}$ To confirm the influence of bulky $N$-Cbz or $N$-Boc groups on a conformation of 4-5, deprotection of $\mathbf{5}$ (TFA) was carried out to give compound 8 (yield $73 \%$ ). Thus, piperidine 8 shows ${ }^{3} J_{\mathrm{FP}} 5 / 6 \mathrm{~Hz}\left({ }^{19} \mathrm{~F},{ }^{31} \mathrm{P}\right.$ NMR) indicating the less strained arrangement of fluorine substituent and phosphonate moiety in piperidine ring.

The second main type of products - phosphonates $\mathbf{6 a}, \mathbf{b}$ or its enantiomers $7 \mathbf{a}, \mathbf{b}$ possess oxazolidine-2-one fragments and have been formed as a result of substitution of DAST derived leaving group in 1-2a,b by carbonyl electron pair from $N$-Cbz ( $N$-Boc) moieties (pathway b, Scheme 3), analogously to the reaction $N$ Boc protected $\beta$-aminoalcohol with DAST. ${ }^{27}$ Configuration at stereogenic centers in $C \mathrm{HP}$ of both diastereoisomers of 6 or 7 was reversed compared to appropriate diastereoisomer of starting 1$\mathbf{2 a}, \mathbf{b}$. Thus, the structure of major and minor diastereoisomers of non-fluorinated oxazolidine-2-ones $\mathbf{6} \mathbf{a}, \mathbf{b}$ arising from $\mathbf{1 a} \mathbf{a}, \mathbf{b}$ were determined on the base of the NMR spectra and NOESY 
experiments and were determined as the trans $\mathbf{6 a}$ for major and cis $\mathbf{6 b}$ for minor isomers, and respectively their enantiomers trans $\mathbf{7 a}$ and cis $\mathbf{7 b}$ if starting material was $\mathbf{2 a}, \mathbf{b}$. The stereochemical assignment of trans/cis oxazolidinones was applied already for determination of stereochemistry in L-phenylalaninal derived hydroxyphosphonates, serving as suitable substrates for aspartyl protease renin inhibitors. ${ }^{28}$ Moreover, careful inspection of ${ }^{19} \mathrm{~F}$ NMR spectra led to observation of other fluorinated products 9 or 10 visible as traces at $\delta$ : $-226 / 227 \mathrm{ppm}$ with two-bond $\mathrm{H}-\mathrm{F}$ coupling constants value being about ${ }^{2} J_{\mathrm{FH}} 47 \mathrm{~Hz}$ and ${ }^{2} J_{\mathrm{FP}} 77 \pm$ $2 \mathrm{~Hz}$, analogically to $\beta$-amino- $\alpha$-fluoroalkylphosphonates. ${ }^{16}$ Compound $\mathbf{9}$ was formed solely from $\mathbf{1 a}$ as a second regioisomer of aziridinium ring opening the most probably (pathway a, Schemes 3 and 1). Analogically, compound $\mathbf{1 0}$ derived from $\mathbf{2 a}$. The resulting ratio of products of the reaction of $\mathbf{1 a}, \mathbf{b}$ as well as 2a,b with various fluorinating agents (crude, ${ }^{31} \mathrm{P}$ NMR), with reaction conditions are presented below (Table 1 ). The presented experiments indicated, that in both cases from 1a,b as well as from $\mathbf{2 a , b}$ three analogous type of compounds were formed and in different temperatures ranges similar ratio of products was observed (DCM, 4 equiv. of DAST). We have determined that compounds 4 and 5, as well as $\mathbf{6 a}$ or 7a, were formed from 1a or $2 \mathbf{a}$ while from $\mathbf{1 b}$ or $\mathbf{2 b}$ only bicyclic $\mathbf{6 b}$ or $7 \mathbf{b}$ were produced. Compound $\mathbf{9}$ arising from major diastereoisomer of 1a was visible as traces in ${ }^{31} \mathrm{P}$ NMR while in the reaction carried out at a higher temperature slightly higher contribution of fluoride 9 was detected. On the other hand, the reactions of $\mathbf{1 a , b}$ or $\mathbf{2 a , b}$ (with a different ratio of stereoisomers) carried out with Deoxofluor (RT, $24 \mathrm{~h}$ ) gave the same products 4-7, 9-10 with a parallel ratio to reaction with DAST. Moreover, the reactions of $\mathbf{1 a , b}$ (3.3 : 1, d.r.) or $\mathbf{2 a , b}$ (37 : 1, d.r.) with PyFluor (DBU, toluene, RT, 5 d) gave alkylphosphoryl pyridine-2-sulfonates 11a,b or 12a,b (3:1 or $74: 1$, d.r.) with yields $78 \%$ and $74 \%$, respectively (Scheme 5). Thus, the reaction of $\mathbf{1 a}, \mathbf{b}$ with PyFluor gave $\mathbf{1 1 a}, \mathbf{b}$ as a mixture of two appropriate diastereoisomers without any configuration changes analogically to starting materials. The positions of signals in ${ }^{31} \mathrm{P}$ NMR were shifted toward higher field $\left(\delta_{\mathrm{P}} 15.1 /\right.$ 14.7 ppm for 11a or $\delta_{\mathrm{P}}$ 15.4/15.5 ppm for 12a), comparing with $\alpha$ hydroxyphosphonates 1-2a,b. The formation of sulfonates instead of fluorides was also already reported. ${ }^{29}$ Also, Kaźmierczak et al. reported the sulfonates formation during fluorination of $\alpha$-hydroxyphosphonate analogues of amino acids such as phenylalanine possessing phthaloyl protecting group. ${ }^{17}$

On the base of the results described for prolinols $\mathbf{1 - 2 a}, \mathbf{b}$ we next examined the fluorination of diastereoisomeric mixture of 3a,b having benzyl as $N$-protecting group (Table 2).
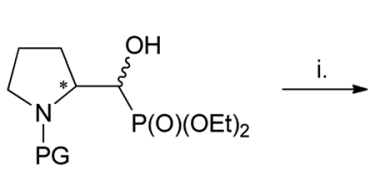

1a,b $P G=C b z$ $2 \mathbf{a}, \mathbf{b} P G=B O c$

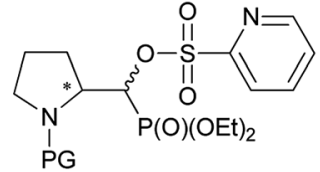

$11 a, b P G=C b z$ $12 \mathrm{a}, \mathrm{b} P \mathrm{PG}=\mathrm{BOC}$
Scheme 5 Reaction of 1-2a,b with PyFluor (PyFluor, DBU, MePh, RT, 5d; $11 a, b$ 78\%, 12a,b 74\%).
Table 2 Fluorination of $3 a, b$ with different fluorinating agents ${ }^{a}$

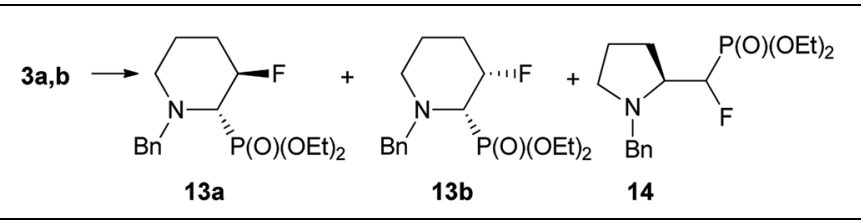

\section{Substrate}

\begin{tabular}{|c|c|c|c|c|c|c|}
\hline$: 3 \mathbf{b}$ & d.r. & Cond. & 13a & $13 b$ & 14 & Yields $[\%]^{b}$ (d.r.) \\
\hline \multirow[t]{5}{*}{$\mathrm{P}(\mathrm{O})(\mathrm{OEt})_{2}$} & $1.1: 1$ & $\mathrm{i}$ & 3.2 & 1 & - & $59(3.2: 1)$ \\
\hline & $2.1: 1$ & $\mathrm{ii}^{c}$ & 9.8 & 1 & - & $49(11.2: 1)$ \\
\hline & $2.1: 1$ & iii & 34 & 1 & - & $48(20: 1)$ \\
\hline & $2.1: 1$ & iv & 5.7 & 1 & - & $58(6.3: 1)$ \\
\hline & $1.9: 1$ & $\mathrm{v}^{d}$ & 2.2 & - & 1 & $19(-)$ \\
\hline
\end{tabular}

${ }^{a}$ (i) DAST, $0{ }^{\circ} \mathrm{C} \rightarrow 45{ }^{\circ} \mathrm{C}(1 \mathrm{~h})$; (ii) DAST, $-78{ }^{\circ} \mathrm{C}(1 \mathrm{~h}) \rightarrow 45{ }^{\circ} \mathrm{C}(0.75 \mathrm{~h})$; (iii) DAST, $-78{ }^{\circ} \mathrm{C}(1 \mathrm{~h}) \rightarrow 45^{\circ} \mathrm{C}(0.75 \mathrm{~h})$, RT (3 h); (iv) Deoxofluor, RT ( 24 h); (v) PyFluor, DBU, MePh, RT, 5 d. ${ }^{b}$ Isolated yields ( ${ }^{31} \mathrm{P}$ NMR). ${ }^{c} 27 \%$ unreacted $3 b .{ }^{d} 44 \%$ unreacted $3 \mathbf{b}$.

When the reaction of 3a,b (2.1 : 1 d.r.) with DAST was set up at $-78{ }^{\circ} \mathrm{C}$, next was carried out at $45{ }^{\circ} \mathrm{C}$ for $0.75 \mathrm{~h}$ we observed mainly transformation of $3 \mathbf{a}$ into fluorinated product 13a. In addition, while both isomers $\mathbf{3 a}$ and $\mathbf{3 b}$ were consumed, ratio 13a : 13b was not corresponding to starting d.r. ratio, presumably due to the presence of other product, not isolated $\left(\delta_{\mathrm{P}}\right.$ : $10 \mathrm{ppm}$, in the crude reaction mixture). On the other hand, the reaction condition $-78{ }^{\circ} \mathrm{C}(1 \mathrm{~h}) \rightarrow 45{ }^{\circ} \mathrm{C}$ for $1 \mathrm{~h}$ followed by treatment at RT for $3 \mathrm{~h}$ gave two fluorinated phosphonates 13a,b without by-product ( $\left.{ }^{31} \mathrm{P} \mathrm{NMR}\right)$ with the isolated yield $59 \%$. The separate experiment indicated that compound $\mathbf{1 3 b}$ is formed from $\mathbf{3 b}$, and for its formation the higher temperature $\left(45^{\circ} \mathrm{C}, 0.75 \mathrm{~h}\right.$ ) was necessary. To compare, the reaction of $\mathbf{3 a}, \mathbf{b}$ with Deoxofluor gave 13a,b with lower diastereoselectivity comparing to reaction with DAST. Surprisingly, the down-field shifted two sets of signals corresponded to compounds 13a and 13b and located around $\delta:-146 \mathrm{ppm}\left({ }^{3} J_{\mathrm{FP}} 3 \mathrm{~Hz}\right)$ and at $\delta$ : $-145 \mathrm{ppm}\left({ }^{3} J_{\mathrm{FP}} 64 \mathrm{~Hz}\right)$ in ${ }^{19} \mathrm{~F}$ NMR indicated that 13a and 13b have different structures comparing piperidines $\mathbf{4}$ and $\mathbf{5}$. Nevertheless, the careful analysis of ${ }^{13} \mathrm{C}$ NMR indicated characteristic signals and coupling constants values for C-3 at $\delta$ : $96 \mathrm{ppm}\left({ }^{1} J_{\mathrm{CF}} 180 \mathrm{~Hz}\right), \mathrm{C}-2$ at $\delta: 65 \mathrm{ppm}\left({ }^{1} J_{\mathrm{CP}} 125 / 150 \mathrm{~Hz},{ }^{2} J_{\mathrm{CF}} 26 /\right.$ $22 \mathrm{~Hz}$ ) confirming that both compounds are diastereoisomers. On the base of ${ }^{19} \mathrm{~F}-{ }^{1} \mathrm{H}$ HOESY and NOESY experiments, the arrangement of substituents in 13a was determined (Scheme 6). Thus, NOE's between fluorine atom and protons: $\mathrm{H}-2$ as well as $\mathrm{H}-4$ (not shown) and $\mathrm{H}-5$ indicated boat conformation and $\mathrm{C}-\mathrm{P}$ and $\mathrm{C}-\mathrm{F}$ in a gauche arrangement, additionally confirmed by the value of ${ }^{3} J_{\mathrm{H} 4 \mathrm{~F}} 26 \mathrm{~Hz}$ indicating coupling of fluorine with equatorial H-4 (syn-periplanar). While compound 13a had ${ }^{3} J_{\mathrm{FP}}$ $4 \mathrm{~Hz}$, analogically to less strained $\mathbf{8}$, in case of compound $\mathbf{1 3 b}$ we have observed analogous vicinal coupling constants as piperidines 4 and $5\left({ }^{3} J_{\mathrm{FP}} 63 \mathrm{~Hz}\right)$ suggesting eclipsed conformation, with dihedral angle value c.a. $0^{\circ}$ between $\mathrm{C}-\mathrm{P}$ and $\mathrm{C}-\mathrm{F}$ bond (equatorials). Additionally, ${ }^{19} \mathrm{~F}-{ }^{1} \mathrm{H}$ HOESY experiments showing NOEs between a fluorine atom and protons: $\mathrm{H}-2, \mathrm{H}-4$ and $\mathrm{H}-5$, analogically to compound 4 . These observations allow us to 

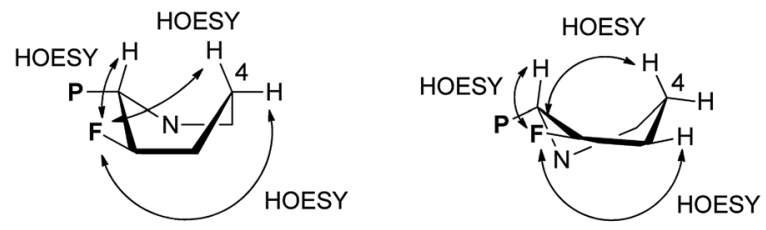

$$
\begin{aligned}
& J_{\mathrm{PF}}=4 \mathrm{~Hz} \quad J_{\mathrm{FH} 4}=26 \mathrm{~Hz} \\
& J_{\mathrm{PF}}=63 \mathrm{~Hz} \quad J_{\mathrm{FH} 4}=37 \mathrm{~Hz} \\
& 13 a \\
& \text { 13b } \\
& P=-P(O)(O E t)_{2} ; \quad N=-N-B n
\end{aligned}
$$

Scheme 6 The conformations of $13 \mathrm{a}$ and $13 \mathrm{~b}$ with observed ${ }^{19} \mathrm{~F}-{ }^{1} \mathrm{H}$ NOEs correlations and some values of coupling constants.

propose configuration $(2 S, 3 R)$ for $13 \mathbf{a}$ and $(2 S, 3 S)$ for piperidine 13b with trans- and cis-arrangements of fluorine and phosphonate group in a six-member ring. ${ }^{25}$ Analogous reaction of $\mathbf{3 a , b}$ with PyFluor (DBU, toluene) led to 13a in addition to $\beta$-amino- $\alpha$ fluoroalkylphosphonates 14 (2.2:1, crude 13a:14 ratio). Moreover, remaining diastereoisomer $\mathbf{3 b}$ stayed intact in the reaction mixture, while reaction at a higher temperature $\left(45^{\circ} \mathrm{C}\right.$, $0.75 \mathrm{~h}$ ) led to decomposition of starting materials. These results are contrary to the reaction of $\beta$-amino- $\alpha$-hydroxyalkylphosphonates with PyFluor where mainly $\alpha$-fluoroalkylphosphonates were formed, ${ }^{17}$ although the amount of the second regioisomer in our case was higher compared to the analogous reaction of $\mathbf{3 a} \mathbf{a}, \mathbf{b}$ with DAST.

Taking into account the neighbouring groups participation in deoxyfluorination of $\alpha$-hydroxyphosphonate proline derivatives, we have decided to investigate similar reaction on serine derivatives having $N$-Cbz, $N$-Boc, and $N$-Bn protecting groups. Thus, the reaction with DAST $\left[-78{ }^{\circ} \mathrm{C}(3 \mathrm{~h}) \rightarrow \mathrm{RT}(16 \mathrm{~h})\right]$ carried on 15a,b or 16a,b [99: 1 d.r., $\left(4 S, 1^{\prime} R,: 4 R, 1^{\prime} S\right)$ ] gave two type of products: bicyclic 17 and aziridines 18 with yields $32 \%$ and $17 \%$ (or 17 and 19 with yields $40 \%$ and 56\%, respectively) (Scheme 7).

Similarly, to the formation of $\mathbf{6 a}, \mathbf{b}$, bicyclic oxazolidine-2-one 17 arose by the attack of carbamate $\mathrm{C}=\mathrm{O}$ electron pair (from $\mathrm{Cbz}$ or Boc) on leaving group $\left(-\mathrm{OSF}_{2} \mathrm{~N}(\mathrm{Et})_{2}\right)$ coming from the reaction of an alcohol moiety with DAST (Scheme 7). On the base of NMR analysis, we were able to assign stereochemistry of compound 17. Thus, diagnostic signals located at $\delta_{\mathrm{H}} 4.38 \mathrm{ppm}$ (dd, $J 6 \mathrm{~Hz}, \mathrm{CHP}$ ) and at $\delta_{\mathrm{H}} 4.54 \mathrm{ppm}(\mathrm{ddt}, J 15,7,6 \mathrm{~Hz}, \mathrm{CHCHP})$ indicated $(1 S, 7 \mathrm{a} S)$ diastereoisomer of 17 , and additional NOESY experiments confirmed that both protons are on the opposite side of oxazolidinone ring. Moreover, coupling constants value ${ }^{3} J_{\mathrm{PH}} 15 \mathrm{~Hz}$ in case of 17 corresponded to dihedral-angle dependence in phosphonates. ${ }^{30}$ Similar value ${ }^{3} J_{\mathrm{PH}} 11 \mathrm{~Hz}$ was also reported by De La Cruz et al. and confirmed trans oxazolidine-2-one formation. ${ }^{31}$ Second isolated type of products, aziridines 18 or 19 were formed by attack of electrons from neighbouring nitrogen atom $(\mathrm{N}$-Boc, $\mathrm{Cbz})$ on hydroxyl derived leaving group $\left(-\mathrm{OSF}_{2} \mathrm{~N}(\mathrm{Et})_{2}\right)$, as in case of first step of $\mathbf{4}$ and $\mathbf{5}$ formation (pathway a, Scheme 3), with subsequent removal of $\mathrm{N}, \mathrm{O}$-isopropylidene protecting group. These assumptions were confirmed by NMR spectroscopy, as well as the transformation of 19 , to known acetyl derivatives $20^{32}$ additionally proving<smiles>CC1(C)OC[C@@H](C(O)P)N1C(=O)O</smiles><smiles>CC1(C)OC[C@H]2[C@@H](P)OC(=O)N21</smiles><smiles>[R]OCC1[C@@H](P)N1P</smiles>

15a $P G=C b z$

17

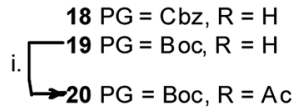

$\mathbf{P}=\mathrm{P}(\mathrm{O})(\mathrm{OEt})_{2}$

Scheme 7 Reaction of 15-16a with DAST (i) or DeoxoFluor (ii) from 15a: DAST: $1732 \%$ and 18a 17\%; from 16a (Table 3), and preparation of 20 ((i) $\mathrm{Ac}_{2} \mathrm{O}, \mathrm{K}_{2} \mathrm{CO}_{3}, \mathrm{AcOEt}, 20$ 82\%).

configuration $(2 S, 3 S)$ of compound 19. Moreover, aziridine 19 existed as a mixture of two rotamers that could be separated by the chromatography techniques.

The formation of aziridine from aziridinium ion by DAST treatment is contrary to known ring-expansion reactions observed for hydroxyphosphonate derivatives of prolinal 1a,b3a,b. However, treatment of hydroxy diazepan-2-ones ${ }^{33}$ or indolizine $^{34}$ derivatives with DAST followed by the nitrogen participation yielded ring contractions as well. On the other hand, application of DAST or Deoxofluor with 16a under varied conditions gave aziridine 19 and phosphonates 17 and/or 21, 22a,b respectively (Table 3 ).

Surprisingly, when the temperature of the reaction mixture was increased $\left(0{ }^{\circ} \mathrm{C} \rightarrow \mathrm{RT}, 0.75 \mathrm{~h}\right)$ as a major product oxazolidine-2-one 21 (after workup, isolated yield 38\%), with a minor aziridine 19, were obtained. Moreover, extended reaction time at $\mathrm{RT}\left[0{ }^{\circ} \mathrm{C}(0.5 \mathrm{~h}) \rightarrow \mathrm{RT}(16 \mathrm{~h})\right]$ gave fluoride 22a (isolated yield $37 \%$ ). Analogous treatment of 16 a with DeoxoFluor gave the same results as with DAST. The structure and stereochemistry of compound $\mathbf{2 1}$ were assumed to be analogous

\begin{tabular}{|c|c|c|c|c|c|}
\hline \multirow{2}{*}{$\begin{array}{l}\text { Substrate } \\
\text { 16a }\end{array}$} & \multirow[b]{2}{*}{ Cond. } & \multicolumn{4}{|c|}{ Ratio (isolated yield\%) } \\
\hline & & 17 & 21 & $22 a, b$ & 19 \\
\hline \multirow{5}{*}{$(\mathrm{EtO})_{2}(\mathrm{O}) \mathrm{P}$} & $\mathrm{i}$ & $2.1(40)$ & - & - & $1(33)$ \\
\hline & ii & $1.8(38)$ & $1(25)$ & - & $1.2(10)$ \\
\hline & & $1(4)$ & $9.4(38)$ & - & $1.9(8)$ \\
\hline & & & $1(-)$ & $16(20: 1)$ & $3(5)$ \\
\hline & $\mathrm{v}$ & $1.6(34)$ & - & - & $1(18)$ \\
\hline
\end{tabular}
to 17 , since only $\mathrm{N}, \mathrm{O}$-isopropylidene protecting group was

Table 3 Fluorination of 16a with DAST or Deoxofluor in varied reaction conditions ${ }^{a}$

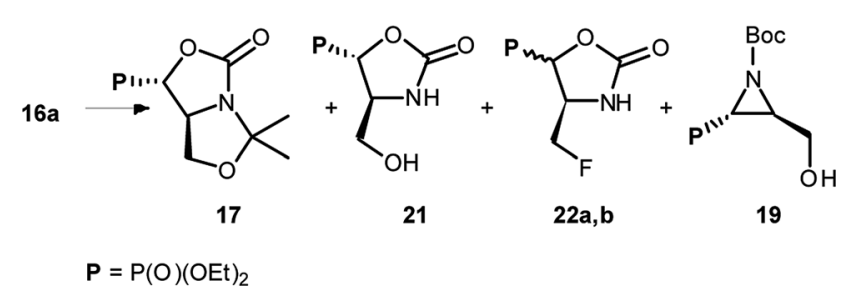

${ }^{a}$ (i) DAST, $-78^{\circ} \mathrm{C}(3 \mathrm{~h}) \rightarrow \mathrm{RT}(16 \mathrm{~h})$; (ii) DAST, $-78^{\circ} \mathrm{C} \rightarrow 0{ }^{\circ} \mathrm{C}(1 \mathrm{~h})$; (iii) DAST, $0{ }^{\circ} \mathrm{C} \rightarrow \mathrm{RT}(0.5 \mathrm{~h})$; (iv) DAST, $-78^{\circ} \mathrm{C}(3 \mathrm{~h}) \rightarrow 0{ }^{\circ} \mathrm{C}(0.5 \mathrm{~h}) \rightarrow \operatorname{RT}(16$ h); (v) Deoxofluor, RT (30 h). 
<smiles>CCN(CC)S(C)(F)(F)(F)CO</smiles>

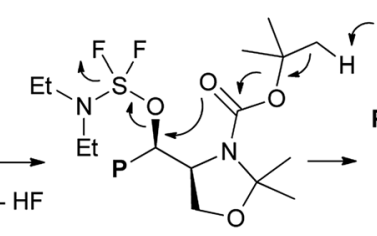

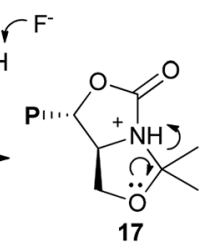
$16 a$<smiles>O=C1N[C@H](CF)[C@@H](P)O1</smiles>

22a or<smiles>O=C1N[C@H](CO)[C@@H](P)O1</smiles>

21

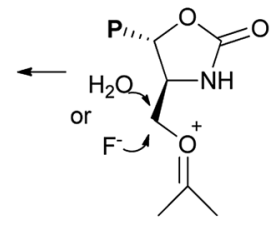

$P=P(O)(O E t)_{2}$

Scheme 8 The mechanism of DAST-induced transformation of $16 \mathrm{a}$ leading to 21 or $22 a$.

removed. Thus trans-oxazolidinone ring geometry was confirmed by NMR spectra analysis $\left({ }^{3} J_{\mathrm{HP}} 18 \mathrm{~Hz}\right)$ indicating $(4 S, 5 S)$-21 configurations. On the base of these observations, we propose the mechanism of DAST-induced transformation of $16 \mathbf{a}$ yielding $\mathbf{2 1}$ or $\mathbf{2 2 a}$ (Scheme 8).

In the beginning, we observed the formation of bicyclic oxazolidine-2-one 17. Subsequent removal of $\mathrm{N}, \mathrm{O}$-isopropylidene protecting group gave after workup hydroxymethyl derivative $\mathbf{2 1}$ or due to the attack of fluoride " $\mathrm{HF}_{2}{ }^{-}$" (extended reaction time) led to fluorinated phosphonate oxazolidine-2-one 22a. Similar DAST-mediated removal of $O$-isopropylidene group has been reported for deoxyfluorination of $\alpha$-hydroxyphosphonate derivatives of glyceraldehyde yielding fosfomycin analogue. ${ }^{21}$ On the other hand, during the reaction of 16a with DAST, we have observed the $\mathbf{2 2 b}$ formation, which epimerized during reaction and purification on silica gel to give exclusively 22a (NMR). The presence of fluoride in exocyclic methyl group is confirmed by the high-field chemical shift of $\mathrm{CH}_{2} \mathrm{~F}$ signal at $\delta_{\mathrm{F}}$ $\sim-230 /-235 \mathrm{ppm}(\mathrm{td}, J 47,19 / 22 \mathrm{~Hz})$. The configurations of 22a as $(4 S, 5 S)$ has been confirmed by $2 \mathrm{D}$ NMR experiments. Thus, ${ }^{19} \mathrm{~F}-{ }^{1} \mathrm{H}$ HOESY experiment showed NOEs between a fluorine atom and geminal protons in $\mathrm{CH}_{2} \mathrm{~F}$ as well as with $\mathrm{H}-4$ (CHP) while no NOEs between $\mathrm{H}-4$ and $\mathrm{H}-5$ has been detected $\left({ }^{1} \mathrm{H}-{ }^{1} \mathrm{H}\right.$ NOESY) and proved trans arrangement of protons in oxazolidine-2-one ring. Moreover, the reaction of 15a with DAST at RT yielded $\mathbf{2 1}$ and 22a. Analogously, the deprotection/ deoxyfluorination were applied in case of synthesis of $\mathrm{N}$-protected L-fluoroalanine. Thus, the desired compound has been obtained by a desilylation/deoxofluorination reaction of oxazolidinone analogue of L-serine using XtalFluor-E in the presence of triethylamine trihydrofluoride. ${ }^{35}$

At the same time, the reaction performed on 15a as well as on 16a with PyFluor gave sulfonates 23 or 24 with $60 \%$ and $47 \%$ isolated yields (Scheme 9), similarly to the reaction of $\mathbf{1 - 2 a , b}$ with PyFluor leading to compounds 11-12a,b.

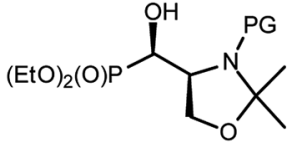

15a $P G=\mathrm{Cbz}$ $16 a \mathrm{PG}=\mathrm{BOc}$

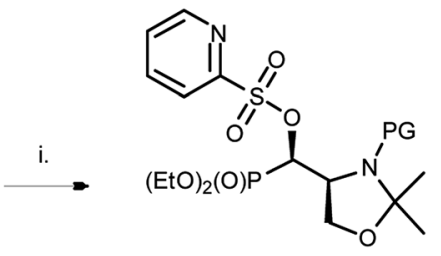

$23 P G=\mathrm{Cb} z$ $24 P G=B o c$
Scheme 9 Reaction of 15-16a with PyFluor. (i) PyFluor, DBU, MePh, RT, 5d; 23a 60\%, 24a (47\%).

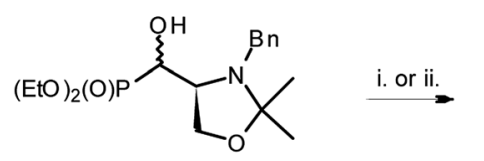

$25 a, b$

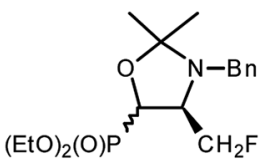

26a,b
Scheme 10 Reaction of 25a,b with DAST or PyFluor. (i) DAST, RT $0.5 \mathrm{~h}$ (26a 58\%); (ii) PyFluor, DBU, MePh, RT, 5d; 26a (37\%).

To compare, the reaction of $25 a, b$ [12.5: 1 or $3.4: 1$, d.r., $\left.\left.\left(4 S, 1^{\prime} R: 4 R, 1^{\prime} S\right)\right]\right)$ with DAST at RT $(0.5 \mathrm{~h})$ or at $0{ }^{\circ} \mathrm{C}(2 \mathrm{~h}) \rightarrow \mathrm{RT}(2$

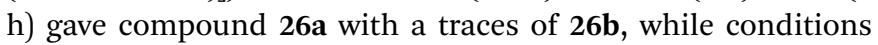
starting from $-78{ }^{\circ} \mathrm{C}(3 \mathrm{~h}) \rightarrow 0{ }^{\circ} \mathrm{C}(1 \mathrm{~h})$ led to the compound 26a only (as two rotamers in ratio $98: 2,58 \%$ of yield). Moreover, the reaction of $25 \mathbf{a}, \mathbf{b}(3.4: 1)$ with PyFluor (PyFluor (2.4 eq.), DBU (4 eq.), MePh, RT, 5 d) gave only 26a (37\%) (Scheme 10). The mechanism of the formation of $\mathbf{2 6 a}$ relied on the attack of fluoride during removal of $O$-isopropylidene protection (as depicted on Scheme 8) followed by substitution of leaving group $\left(-\mathrm{OSF}_{2} \mathrm{~N}(\mathrm{Et})_{2}\right)$ by oxygen atom derived from just created carbonyl group. While ${ }^{1} \mathrm{H},{ }^{13} \mathrm{C}$ and ${ }^{19} \mathrm{~F}$ NMR spectra of 26 a are similar to 22a and indicated trans arrangement of protons in oxazolidine-2-one ring, ${ }^{28}$ as well as presence of $\mathrm{CH}_{2} \mathrm{~F}$ group, the chemical shifts of signals in ${ }^{31} \mathrm{P}$ NMR are distinctively different from 22a $\left(\delta_{\mathrm{P}} 15.7\right)$ but fit to structure of oxazolidine ring in 26a $\left(\delta_{\mathrm{P}}\right.$ 21.6) ${ }^{30}$ Additionally, NOESY experiments indicating correlations between $\mathrm{CHP}-\mathrm{CHHF}$, while other relationship for $\mathrm{CHN}$ and $\mathrm{CH} H \mathrm{~F}$ as well as NOE between a fluorine atom and $\mathrm{CHN}$ $\left({ }^{1} \mathrm{H}-{ }^{1} \mathrm{H}\right.$ NOESY, ${ }^{1} \mathrm{H}-{ }^{19} \mathrm{~F}$ HOESY) confirmed the structure of $26 \mathbf{a}$ as trans oxazolidine.

\section{Conclusions}

In summary, we have discussed the DAST/DeoxoFluor induced transformation of proline or serine derived hydroxyphosphonates having - $\mathrm{Cbz}$, -Boc and -Bn moieties as $N$ - protecting groups. It seems that diastereoselective course of deoxyfluorination depends on the participation of the neighbouring group and applied reagent. Thus, the reaction of $N-\mathrm{Cbz}$ or $N$-Boc prolinols 1-2a with DAST or Deoxofluor, through aziridinium intermediate and ring opening gave fluorinated piperidine phosphonates $\mathbf{4}$ or $\mathbf{5}$ and minors pyrrolidine fluorides 9 or 10, respectively. In addition, due to the participation 
of $N$-protecting group oxazolidine-2-ones 6-7a were formed. Analogically DAST/DeoxoFluor treatment of the second diastereoisomer of 1-2b led only to oxazolidine-2-ones 6-7b. Similarly, the reaction of $N$-Cbz or $N$-Boc protected serinols 15,16a with DAST or Deoxyfluor yielded analogous oxazolidine-2-one 17 transforming during workup to 21 or by fluorination to $\mathbf{2 2 a}, \mathbf{b}$, as presented in proposed mechanism. As a second path of the reaction, aziridines 18 and 19 were isolated as the ring contraction products. Only in case of deoxyfluorination of $\mathrm{N}$ benzyl prolinols $\mathbf{3 a}, \mathbf{b}$ both diastereoisomers of $\beta$-fluoropiperidine- $\alpha$-phosphonates 13a,b were formed, while the reaction of protected $N$-benzyl serinol 25a,b gave fluorinated oxazolidines 26a,b. Moreover, application of PyFluor in the reactions with 12a,b and 15-16a,b gave sulfonates 11-12a,b and 23-24. These studies gave an example of the synthesis of valuable building blocks for the asymmetric synthesis of peptide analogues as well as versatile substrates in the synthesis of biologically active species since amino phosphonates mimic naturally occurring $\alpha$ amino acids.

\section{Experimental part}

\section{General information}

${ }^{1} \mathrm{H}$ NMR, ${ }^{13} \mathrm{C}$ NMR, ${ }^{19} \mathrm{~F}$ NMR and ${ }^{31} \mathrm{P}$ NMR spectra were performed on Bruker ASCEND 400 (400 MHz), Bruker ASCEND 600 $(600 \mathrm{MHz})$ spectrometers in $\mathrm{CDCl}_{3}$ solution. All 2D NMR spectra were recorded on Bruker ASCEND 600 (600 MHz) spectrometer. Chemical shifts of ${ }^{1} \mathrm{H}$ NMR were expressed in parts per million downfield from tetramethylsilane (TMS) as an internal standard $(\delta=0)$ in $\mathrm{CDCl}_{3}$ or $\mathrm{CDCl}_{3}(\delta=7.26)$. Chemical shifts of ${ }^{13} \mathrm{C} \mathrm{NMR}$ were expressed in parts per million downfield and upfield from $\mathrm{CDCl}_{3}$ as an internal standard $(\delta=77.16)$. Chemical shifts of ${ }^{19} \mathrm{~F}$ NMR were expressed in parts per million upfield from $\mathrm{CFCl}_{3}$ as an internal standard $(\delta=0)$ in $\mathrm{CDCl}_{3}$. Chemical shifts of ${ }^{31} \mathrm{P}$ NMR were expressed in parts per million in $\mathrm{CDCl}_{3}$. All d.r. ratios were evaluated on the basis of ${ }^{31} \mathrm{P}$ NMR in crude reaction mixture. High-resolution mass spectra were recorded by electron spray (MS-ESI) techniques using QToF Impact HD Bruker spectrometer. Reagent grade chemicals were used and solvents were dried by refluxing with sodium metal (toluene), with $\mathrm{CaH}_{2}$ (DCM) and distilled under an argon atmosphere. All moisture sensitive reactions were carried out under an argon atmosphere using oven-dried glassware. Reaction temperatures below $0{ }^{\circ} \mathrm{C}$ were performed using a cooling bath (liquid $\mathrm{N}_{2} / i$-PrOH). TLC was performed on Merck Kieselgel 60- $\mathrm{F}_{254}$ with EtOAc/hexane, EtOAc//EtOAc/ $i$-PrOH/ $/ \mathrm{H}_{2} \mathrm{O}$ (4:1:2, upper layer; SSE) or $\mathrm{CHCl}_{3} / \mathrm{MeOH}$ as developing systems, and products were detected by inspection under UV light $(254 \mathrm{~nm})$ and with a solution of potassium permanganate. Merck Kieselgel 60 (230-400 mesh) was used for column chromatography. DAST was supplied by Sigma Aldrich or Apollo Scientific. All remaining starting materials were supplied by Sigma Aldrich. Substrates have to be well dried prior to use. Compounds 1a,b, 3a,b, 15a,b, 25a,b; ${ }^{36}$ $\mathbf{2 a}, \mathbf{b} \mathbf{b}^{\mathbf{6} c} \mathbf{1 6 a}, \mathbf{b}^{37}$ were prepared as described.

1. Procedures for the reactions with fluorinating agents

1.1. Procedure A. Reactions of $\alpha$-hydroxyphosphonates with $D A S T$. To a solution of DAST (4 eq.) in dry $\mathrm{CH}_{2} \mathrm{Cl}_{2}(7 \mathrm{~mL})$ in a cooling bath (liquid $\mathrm{N}_{2} / i-\mathrm{PrOH}$, or ice), $\alpha$-hydroxyphosphonates (1 eq.) in dry $\mathrm{CH}_{2} \mathrm{Cl}_{2}(3 \mathrm{~mL})$ was added slowly and a reaction mixture was kept accordingly to notes below. Then the reaction mixture was diluted with water $(5 \mathrm{~mL})$, extracted with $\mathrm{CH}_{2} \mathrm{Cl}_{2}(3 \times 15 \mathrm{~mL})$, dried $\left(\mathrm{Na}_{2} \mathrm{SO}_{4}\right)$, filtered and concentrated. The products were isolated using column chromatography $\left(\mathrm{CHCl}_{3} / \mathrm{MeOH}\right.$ or EtOAc/hexane).

1.2. Procedure B. Reactions of $\alpha$-hydroxyphosphonates with DeoxoFluor. To a solution of $\alpha$-hydroxyphosphonates (1 eq.) in dry $\mathrm{CH}_{2} \mathrm{Cl}_{2}(5 \mathrm{~mL})$, DeoxoFluor (2 eq.) was added and reaction mixture was stirred at room temperature for $24 \mathrm{~h}$ under ambient atmosphere. Then the reaction mixture was diluted with water (5 mL), extracted with $\mathrm{CH}_{2} \mathrm{Cl}_{2}(3 \times 5 \mathrm{~mL})$, dried over $\mathrm{Na}_{2} \mathrm{SO}_{4}$, and filtered. Removal of solvent at reduced pressure gave a residue, which was then purified using column chromatography $\left(\mathrm{CHCl}_{3} / \mathrm{MeOH}\right.$ or EtOAc/hexane).

1.3. Procedure C. Reactions of $\alpha$-hydroxyphosphonate with PyFluor. To a solution of $\alpha$-hydroxyphosphonates $(1$ eq.) in dry $\mathrm{CH}_{2} \mathrm{Cl}_{2}$ (5 mL), PyFluor (2.4 eq.) and DBU (4 eq.) was added and reaction mixture was stirred at room temperature for 4 days under ambient atmosphere (monitored by TLC). After reaction was completed, the solvent was removed at reduced pressure, and the products were isolated using column chromatography $\left(\mathrm{CHCl}_{3} / \mathrm{MeOH}\right)$.

Note A1: treatment of $\mathbf{1 a}: \mathbf{1 b}(22.8: 1$ d.r.) according to procedure $\mathrm{A}\left[-78{ }^{\circ} \mathrm{C} \rightarrow 0{ }^{\circ} \mathrm{C}(1.5 \mathrm{~h})\right]$ gave 4 as a mixture with 9 (60 $\mathrm{mg}, 43 \%$ and $8 \%$, respectively, $5.8: 1$ ) and $\mathbf{6 a}, 6 \mathbf{b}$ (38 $\mathrm{mg}$, $45 \%, 9.5$ : 1 d.r.).

Note A2: treatment of $\mathbf{1 a}: \mathbf{1 b}(2.7: 1$ d.r. $)$ according to procedure A $\left[-78{ }^{\circ} \mathrm{C}(3 \mathrm{~h})\right.$; RT $\left.(1 \mathrm{~h})\right]$ gave $4(43 \mathrm{mg}, 36 \%)$ and 6a,6b (47 mg, 56\%, $1.86: 1$ d.r.).

Note A3: treatment of $2 \mathbf{a}: \mathbf{2 b}$ (3.8:1 d.r.) according to procedure A $\left[-78{ }^{\circ} \mathrm{C}(3 \mathrm{~h})\right.$; RT $\left.(1 \mathrm{~h})\right]$ gave $5(60 \mathrm{mg}, 38 \%)$ and 7a,7b (65 mg, 53\%, $1.9: 1$ d.r.).

Note A4: treatment of $3 \mathbf{a}: 3 \mathbf{b}$ (1.1:1 d.r.) according to procedure $\mathrm{A}\left[0{ }^{\circ} \mathrm{C} \rightarrow 45{ }^{\circ} \mathrm{C}(1 \mathrm{~h})\right]$ gave $13 \mathbf{a}, \mathbf{b}$ in few fractions containing different ratio of diastereoisomers $(125 \mathrm{mg}, 59 \%$, 6.2 : 1 d.r.).

Note A5: treatment of $\mathbf{1 5 a}$ according to procedure $\mathrm{A}\left[0{ }^{\circ} \mathrm{C}(0.5\right.$ h); RT (18 h)] gave 17 (33 mg, 32\%) and 18 (21 mg, 17\%).

Note A6: treatment of $16 \mathbf{a}$ according to procedure $\mathrm{A}\left[-78{ }^{\circ} \mathrm{C}\right.$ (3 h); RT (16 h)] gave 17 (18 mg, 40\%) and 19 (27 mg, 33\%).

Note A7: treatment of $16 \mathrm{a}$ according to procedure $\mathrm{A}\left[0{ }^{\circ} \mathrm{C} \rightarrow\right.$ RT (0.5 h)] gave 17 (5 mg, 4\%), 19 (12 mg, 8\%) and 21 (41 mg, $38 \%)$.

Note A8: treatment of $16 \mathbf{a}$ according to procedure $\mathrm{A}\left[-78^{\circ} \mathrm{C}\right.$ $(3 \mathrm{~h}) \rightarrow 0{ }^{\circ} \mathrm{C}(0.5 \mathrm{~h})$; RT $\left.(16 \mathrm{~h})\right]$; gave 19 (9 mg, 5\%) and 22a,b (59 mg, 37\%).

Note A9: treatment of 25a,b (3.4:1 d.r.) according to procedure A (RT, $0.5 \mathrm{~h}$ ) gave compounds $26 \mathrm{a}(19 \mathrm{mg}, 58 \%)$.

Note B1: treatment of $\mathbf{3 a}: \mathbf{3 b}(2.1: 1$ d.r. $)$ according to procedure B gave compounds 13a,b (48 mg, 5.7 : 1, d.r., 74\%).

Note C1: treatment of $\mathbf{1 a , b}(3.3: 1$ d.r.) according to procedure C, gave 11a,b (72 mg, $3: 1,78 \%$ )

Note C2: treatment of $\mathbf{1 a , b}(24: 1: 1$ d.r.) according to procedure C, gave 11a,b (36 mg, $18: 1,69 \%$ ) 
Note C3: treatment of $\mathbf{2 a , b}(37: 1$ d.r.) according to procedure C, gave 12a,b (42 mg, 74 : 1 d.r., 74\%)

Note C4: treatment of $3 \mathbf{a}: \mathbf{3 b}(1.9: 1$ d.r.) according to procedure $\mathrm{C}$ gave compounds 13a (10 mg, 19\%)

Note C5: treatment of 15a according to procedure $\mathrm{C}$ gave compounds 23 (31 mg, 60\%).

Note C6: treatment of $\mathbf{1 6 a}$ according to procedure $\mathrm{C}$ gave compounds 24 (32 mg, 47\%).

Note C7: treatment of $\mathbf{2 5 a , b}(3.4: 1$ d.r.) according to procedure C gave compounds $26 \mathbf{a}(24 \mathrm{mg}, 37 \%$ ).

(2R,3R)-benzyl 2-(diethoxyphosphoryl)-3-fluoropiperidine-1carboxylate (4). Isolated with a yield $36 \%$ (Note A2) or with $43 \%$ as a mixture with 9 (Note A1) as slightly yellow oil, mixture of two rotamers (1.1: 1). Major rotamer had: ${ }^{1} \mathrm{H}$ NMR $(400 \mathrm{MHz})$ $\delta=7.39-7.33(\mathrm{~m}, 4 \mathrm{H}, \mathrm{Ph}), 7.33-7.30(\mathrm{~m}, 1 \mathrm{H}, \mathrm{Ph}), 5.21(\mathrm{~d}, J=$ $12.3 \mathrm{~Hz}, 1 \mathrm{H}, \mathrm{CHHPh}), 5.12$ (d, $J=12.3 \mathrm{~Hz}, 1 \mathrm{H}, \mathrm{CH} H \mathrm{Ph}), 5.03$ (dd, $J=21.3,19.4 \mathrm{~Hz}, 1 \mathrm{H}, \mathrm{CHP}$ ), 5.02 (dd, $J=46.6,12.2 \mathrm{~Hz}, 1 \mathrm{H}$, $\mathrm{CHF}), 4.17-4.10\left(\mathrm{~m}, 3 \mathrm{H}, \mathrm{NCHH}, \mathrm{OCH}_{2} \mathrm{CH}_{3}\right), 4.09-3.99(\mathrm{~m}, 2 \mathrm{H}$, $\mathrm{OCH}_{2} \mathrm{CH}_{3}$ ), $3.37(\mathrm{td}, J=13.2,2.6 \mathrm{~Hz}, 1 \mathrm{H}, \mathrm{NCH} H), 2.07-2.02(\mathrm{~m}$, $\left.2 \mathrm{H}, \mathrm{CH}_{2} \mathrm{CHF}\right), 1.91-1.76\left(\mathrm{~m}, 1 \mathrm{H}, \mathrm{NCH}_{2} \mathrm{CHH}\right), 1.57-1.48(\mathrm{~m}, 1 \mathrm{H}$, $\left.\mathrm{NCH}_{2} \mathrm{CH} H\right), 1.32\left(\mathrm{t}, J=7.1 \mathrm{~Hz}, 3 \mathrm{H}, \mathrm{OCH}_{2} \mathrm{CH}_{3}\right), 1.24(\mathrm{t}, J=$ $\left.7.1 \mathrm{~Hz}, 3 \mathrm{H}, \mathrm{OCH}_{2} \mathrm{CH}_{3}\right) .{ }^{13} \mathrm{C} \mathrm{NMR}(101 \mathrm{MHz}) \delta=155.37(\mathrm{~d}, J=$ $3.0 \mathrm{~Hz}, C=\mathrm{O}), 136.45,128.50,128.11,127.96(4 \times \mathrm{s}, \mathrm{Ph}), 85.45$ (dd, $J=178.9,19.9 \mathrm{~Hz}, C \mathrm{HF}), 67.72\left(\mathrm{~s}, C \mathrm{H}_{2} \mathrm{Ph}\right), 63.06$ (d, $J=$ $7.3 \mathrm{~Hz}, \mathrm{OCH}_{2} \mathrm{CH}_{3}$ ), 62.48 (d, $J=6.8 \mathrm{~Hz}, \mathrm{OCH}_{2} \mathrm{CH}_{3}$ ), 53.23 (dd, $J$ $=150.2,22.5 \mathrm{~Hz}, C \mathrm{HP}), 41.21\left(\mathrm{~s}, \mathrm{NCH}_{2}\right), 26.36(\mathrm{~d}, J=6.0 \mathrm{~Hz}$, $\mathrm{CH}_{2} \mathrm{CHF}$ ), 19.00 (s, $\mathrm{NCH}_{2} \mathrm{CH}_{2}$ ), 16.36 (d, $J=5.6 \mathrm{~Hz}, \mathrm{OCH}_{2} \mathrm{CH}_{3}$ ), $16.34\left(\mathrm{~d}, J=6.0 \mathrm{~Hz}, \mathrm{OCH}_{2} \mathrm{CH}_{3}\right) .{ }^{19} \mathrm{~F} \mathrm{NMR}(377 \mathrm{MHz}) \delta=-179.55$ to $-180.05(\mathrm{~m}) .{ }^{31} \mathrm{P}\left\{/{ }^{1} \mathrm{H}\right\} \mathrm{NMR}(162 \mathrm{MHz}) \delta=19.24(\mathrm{~d}, J=61.7$ $\mathrm{Hz})$. Minor rotamer had: ${ }^{1} \mathrm{H}$ NMR $(400 \mathrm{MHz}) \delta=7.39-7.31(\mathrm{~m}$, $4 \mathrm{H}, \mathrm{Ph}), 7.33-7.30$ (m, 1H, Ph), 5.20 (d, J=12.3 Hz, 1H, CHHPh), $5.12(\mathrm{~d}, J=12.3 \mathrm{~Hz}, 1 \mathrm{H}, \mathrm{CH} H \mathrm{Ph}), 5.09(\mathrm{dd}, J=44.8,17.7 \mathrm{~Hz}, 1 \mathrm{H}$, $\mathrm{CHF}), 4.86(\mathrm{dd}, J=21.0,18.8 \mathrm{~Hz}, 1 \mathrm{H}, \mathrm{CHP}), 4.26$ (d, $J=13.6 \mathrm{~Hz}$, $1 \mathrm{H}, \mathrm{NCHH}), 4.17-4.10\left(\mathrm{~m}, 2 \mathrm{H}, \mathrm{OCH}_{2} \mathrm{CH}_{3}\right), 4.09-3.99(\mathrm{~m}, 2 \mathrm{H}$, $\left.\mathrm{OCH}_{2} \mathrm{CH}_{3}\right), 3.26(\mathrm{td}, J=13.3,2.7 \mathrm{~Hz}, 1 \mathrm{H}, \mathrm{NCH} H), 2.21-2.12(\mathrm{~m}$, 1H, CHHCHF), 2.11-2.07 (m, 1H, CHHCHF), 1.91-1.76 (m, $1 \mathrm{H}$, $\mathrm{NCH}_{2} \mathrm{CHH}$ ), 1.57-1.48 (m, 1H, $\left.\mathrm{NCH}_{2} \mathrm{CH} H\right), 1.27$ (t, $J=7.1 \mathrm{~Hz}$, $\left.3 \mathrm{H}, \mathrm{OCH}_{2} \mathrm{CH}_{3}\right), 1.22\left(\mathrm{t}, J=7.1 \mathrm{~Hz}, 3 \mathrm{H}, \mathrm{OCH}_{2} \mathrm{CH}_{3}\right) .{ }^{13} \mathrm{C} \mathrm{NMR}(101$ MHz) $\delta=155.73(\mathrm{~d}, J=3.8 \mathrm{~Hz}, C=\mathrm{O}), 136.32,128.48,128.11$, $127.98(4 \times \mathrm{s}, \mathrm{Ph}), 85.31(\mathrm{dd}, J=179.0,20.2 \mathrm{~Hz}, C \mathrm{HF}), 67.70(\mathrm{~s}$, $\mathrm{CH}_{2} \mathrm{Ph}$ ), 63.01 (d, $\left.J=7.1 \mathrm{~Hz}, \mathrm{OCH}_{2} \mathrm{CH}_{3}\right), 62.34(\mathrm{~d}, J=7.1 \mathrm{~Hz}$, $\mathrm{OCH}_{2} \mathrm{CH}_{3}$ ), 54.11 (dd, $\left.J=150.4,22.3 \mathrm{~Hz}, C \mathrm{HP}\right), 40.85\left(\mathrm{~s}, \mathrm{NCH}_{2}\right.$ ), 26.15 (d, $\left.J=5.9 \mathrm{~Hz}, \mathrm{CH}_{2} \mathrm{CHF}\right), 18.82\left(\mathrm{~s}, \mathrm{NCH}_{2} \mathrm{CH}_{2}\right.$ ), 16.44 (d, $J=$ $5.7 \mathrm{~Hz}, \mathrm{OCH}_{2} \mathrm{CH}_{3}$ ), 16.36 (d, $\left.J=5.6 \mathrm{~Hz}, \mathrm{OCH}_{2} \mathrm{CH}_{3}\right) .{ }^{19} \mathrm{~F} \mathrm{NMR}$ (377 MHz) $\delta=-178.86$ to $-179.39(\mathrm{~m}) .{ }^{31} \mathrm{P}\left\{/{ }^{1} \mathrm{H}\right\}$ NMR $(162$ MHz) $\delta=18.96\left(\mathrm{~d}, J=62.0 \mathrm{~Hz}\right.$ ). HRMS (ESI) calcd for $\mathrm{C}_{17} \mathrm{H}_{25^{-}}$ $\mathrm{FNNaO}_{5} \mathrm{P}^{+}\left([\mathrm{M}+\mathrm{Na}]^{+}\right)$: 396.1347 , found: 396.1361 .

(2S,3S)-tert-butyl 2-(diethoxyphosphoryl)-3-fluoropiperidine-1carboxylate (5). Isolated with a yield $38 \%$ (Note A3), as slightly yellow oil, mixture of two rotamers $(1.1: 1)$.

Major rotamer had: ${ }^{1} \mathrm{H}$ NMR $(400 \mathrm{MHz}) \delta=5.07$ (br d, $J=$ $42.0 \mathrm{~Hz}, 1 \mathrm{H}, \mathrm{CHF}$ ), 5.00 (dd, $J=21.5,18.1 \mathrm{~Hz}, 1 \mathrm{H}, \mathrm{CHP}$ ), 4.24$4.09\left(\mathrm{~m}, 4 \mathrm{H}, 2 \times \mathrm{OCH}_{2} \mathrm{CH}_{3}\right), 4.04(\mathrm{br} \mathrm{d}, J=13.6 \mathrm{~Hz}, 1 \mathrm{H}, \mathrm{NCHH})$, $3.30(\mathrm{td}, J=13.3,3.0 \mathrm{~Hz}, 1 \mathrm{H}, \mathrm{NCH} H), 2.16(\mathrm{tdd}, J=13.6,4.7$, $2.3 \mathrm{~Hz}, 1 \mathrm{H}, \mathrm{CHHCHF}), 2.08-2.02$ (m, 1H, CHHCHF), 1.87-1.75 $\left(\mathrm{m}, 1 \mathrm{H}, \mathrm{NCH}_{2} \mathrm{CHH}\right), 1.53-1.50\left(\mathrm{~m}, 1 \mathrm{H}, \mathrm{NCH}_{2} \mathrm{CH} H\right), 1.48(\mathrm{~s}, 9 \mathrm{H}$,
$\left.\mathrm{C}\left(\mathrm{CH}_{3}\right)_{3}\right), 1.34\left(\mathrm{t}, J=6.1 \mathrm{~Hz}, 3 \mathrm{H}, \mathrm{OCH}_{2} \mathrm{CH}_{3}\right), 1.32(\mathrm{t}, J=6.1 \mathrm{~Hz}$, $\left.3 \mathrm{H}, \mathrm{OCH}_{2} \mathrm{CH}_{3}\right) .{ }^{13} \mathrm{C} \mathrm{NMR}(101 \mathrm{MHz}) \delta=154.63(\mathrm{~d}, J=2.9 \mathrm{~Hz}$, $C=\mathrm{O}), 85.56(\mathrm{dd}, J=178.8,2.2 \mathrm{~Hz}, C \mathrm{HF}), 80.58\left(\mathrm{~s}, C\left(\mathrm{CH}_{3}\right)_{3}\right)$, 62.31 (d, $\left.J=6.8 \mathrm{~Hz}, \mathrm{OCH}_{2} \mathrm{CH}_{3}\right), 62.17$ (d, $J=7.1 \mathrm{~Hz}, \mathrm{OCH}_{2} \mathrm{CH}_{3}$ ), 52.35 (dd, $J=149.7,22.5 \mathrm{~Hz}, C \mathrm{HP}), 41.28\left(\mathrm{~s}, \mathrm{NCH}_{2}\right), 28.30$ (s, $\left.\mathrm{C}\left(\mathrm{CH}_{3}\right)_{3}\right), 26.31\left(\mathrm{~d}, J=21.4 \mathrm{~Hz}, \mathrm{CH}_{2} \mathrm{CHF}\right), 19.03\left(\mathrm{~s}, \mathrm{NCH}_{2} \mathrm{CH}_{2}\right)$, 16.42 (d, $J=5.9 \mathrm{~Hz}, \mathrm{OCH}_{2} \mathrm{CH}_{3}$ ), 16.31 (d, $J=6.2 \mathrm{~Hz}, \mathrm{OCH}_{2} \mathrm{CH}_{3}$ ). ${ }^{19} \mathrm{~F}\left\{/{ }^{1} \mathrm{H}\right\}$ NMR $(376 \mathrm{MHz}) \delta=-179.53(\mathrm{~d}, J=63.3 \mathrm{~Hz}) .{ }^{19} \mathrm{~F}$ NMR (376 MHz) $\delta=-179.25$ to $-179.78(\mathrm{~m}) .{ }^{31} \mathrm{P}\left\{/{ }^{1} \mathrm{H}\right\}$ NMR (162 $\mathrm{MHz}) \delta=19.78(\mathrm{~d}, J=62.9 \mathrm{~Hz})$. Minor rotamer: ${ }^{1} \mathrm{H}$ NMR (400 $\mathrm{MHz}) \delta=4.99$ (br d, $J=42.5 \mathrm{~Hz}, 1 \mathrm{H}, \mathrm{CHF}), 4.80$ (dd, $J=24.0$, $20.4 \mathrm{~Hz}, 1 \mathrm{H}, \mathrm{CHP}), 4.23-4.21(\mathrm{~m}, 1 \mathrm{H}, \mathrm{NCHH}), 4.24-4.09(\mathrm{~m}, 4 \mathrm{H}$, $\left.2 \times \mathrm{OCH}_{2} \mathrm{CH}_{3}\right), 3.15(\mathrm{td}, J=13.3,2.9 \mathrm{~Hz}, 1 \mathrm{H}, \mathrm{NCH} H), 2.08-2.02$ (m, 2H, $\left.\mathrm{CH}_{2} \mathrm{CHF}\right), 1.87-1.75\left(\mathrm{~m}, 1 \mathrm{H}, \mathrm{NCH}_{2} \mathrm{CHH}\right), 1.53-1.50(\mathrm{~m}$, $\left.1 \mathrm{H}, \mathrm{NCH}_{2} \mathrm{CH} H\right), 1.48\left(\mathrm{~s}, 9 \mathrm{H}, \mathrm{C}\left(\mathrm{CH}_{3}\right)_{3}\right), 1.36(\mathrm{t}, J=7.1 \mathrm{~Hz}, 3 \mathrm{H}$, $\left.\mathrm{OCH}_{2} \mathrm{CH}_{3}\right), 1.33\left(\mathrm{t}, \mathrm{J}=6.1 \mathrm{~Hz}, 3 \mathrm{H}, \mathrm{OCH}_{2} \mathrm{CH}_{3}\right) .{ }^{13} \mathrm{C}$ NMR (101 MHz) $\delta=154.83$ (d, $J=3.5 \mathrm{~Hz}, C=\mathrm{O}$ ), 85.35 (dd, $J=178.8$, $2.4 \mathrm{~Hz}, C \mathrm{HF}), 80.36\left(\mathrm{~s}, C\left(\mathrm{CH}_{3}\right)_{3}\right), 62.92\left(\mathrm{~d}, J=7.1 \mathrm{~Hz}, \mathrm{OCH}_{2} \mathrm{CH}_{3}\right)$, $62.85\left(\mathrm{~d}, J=7.1 \mathrm{~Hz}, \mathrm{OCH}_{2} \mathrm{CH}_{3}\right), 54.35$ (dd, $J=150.1,22.5 \mathrm{~Hz}$, CHP), 39.96 (s, $\mathrm{NCH}_{2}$ ), 28.27 (s, $\left.\mathrm{C}\left(\mathrm{CH}_{3}\right)_{3}\right), 26.39$ (d, $J=21.6 \mathrm{~Hz}$, $\mathrm{CH}_{2} \mathrm{CHF}$ ), 18.85 (s, $\mathrm{NCH}_{2} \mathrm{CH}_{2}$ ), 16.55 (d, $J=5.6 \mathrm{~Hz}, \mathrm{OCH}_{2} \mathrm{CH}_{3}$ ), $16.42\left(\mathrm{~d}, J=5.9 \mathrm{~Hz}, \mathrm{OCH}_{2} \mathrm{CH}_{3}\right) .{ }^{19} \mathrm{~F}\left\{/{ }^{1} \mathrm{H}\right\} \mathrm{NMR}(376 \mathrm{MHz}) \delta=$ $-179.99(\mathrm{~d}, J=63.0 \mathrm{~Hz}) .{ }^{19} \mathrm{~F}$ NMR $(376 \mathrm{MHz}) \delta=-179.74$ to $-180.25(\mathrm{~m}) .{ }^{31} \mathrm{P}\left\{/{ }^{1} \mathrm{H}\right\}$ NMR $(162 \mathrm{MHz}) \delta=19.70(\mathrm{~d}, J=63.1$ $\mathrm{Hz}$ ). HRMS (ESI) calcd for $\mathrm{C}_{14} \mathrm{H}_{27} \mathrm{FNNaO}_{5} \mathrm{P}^{+}\left([\mathrm{M}+\mathrm{Na}]^{+}\right)$: 362.1503, found: 362.1511.

Diethyl ((1R,7aR)-3-oxohexahydropyrrolo[1,2-c]oxazol-1-yl) phosphonate and diethyl ((1S,7aR)-3-oxohexahydropyrrolo[1,2c]oxazol-1-yl)phosphonate $(\mathbf{6} \boldsymbol{a}, \mathbf{6 b})$ and diethyl ((1S,7aS)-3-oxohexahydropyrrolo[1,2-c]oxazol-1-yl)phosphonate and diethyl ((1R,7aS)-3-oxohexahydropyrrolo[1,2-c]oxazol-1-yl)phosphonate $(7 \boldsymbol{a}, 7 \boldsymbol{b})$. Isolated with a yield $45 \%$ (9.5 : 1 d.r., Note A1) or 56\% (1.86 : 1 d.r., Note A2) or 53\% (1.9: 1 d.r., Note A3) as a transparent oil, mixture of two diastereoisomers.

Major diastereoisomer 6a/7a had: ${ }^{1} \mathrm{H}$ NMR $(400 \mathrm{MHz}) \delta=$ $4.44(\mathrm{~d}, J=4.4 \mathrm{~Hz}, 1 \mathrm{H}, \mathrm{CHP}), 4.27-4.20\left(\mathrm{~m}, 4 \mathrm{H}, 2 \times \mathrm{OCH}_{2} \mathrm{CH}_{3}\right)$, 4.10 (tdd, $J=11.3,6.2,2.7 \mathrm{~Hz}, 1 \mathrm{H}, \mathrm{CHCHP}), 3.66-3.54(\mathrm{~m}, 1 \mathrm{H}$, $\mathrm{NCHH}), 3.25-3.16(\mathrm{~m}, 1 \mathrm{H}, \mathrm{NCH} H), 2.21-2.13(\mathrm{~m}, 1 \mathrm{H}, \mathrm{CH} \mathrm{HCH})$, 2.15-2.06 (m, 1H, $\left.\mathrm{NCH}_{2} \mathrm{CH} \mathrm{H}\right), 2.02-1.92\left(\mathrm{~m}, 1 \mathrm{H}, \mathrm{NCH}_{2} \mathrm{CH} H\right)$, 1.59-1.48 (m, 1H, CHHCH), 1.39-1.33 (m, 6H, $\left.2 \times \mathrm{OCH}_{2} \mathrm{CH}_{3}\right)$. ${ }^{13} \mathrm{C}$ NMR $(101 \mathrm{MHz}) \delta=159.82(\mathrm{~d}, J=3.9 \mathrm{~Hz}, C=\mathrm{O}), 73.80(\mathrm{~d}, J$ $=173.6 \mathrm{~Hz}, C \mathrm{HP}), 63.95\left(\mathrm{~d}, J=6.9 \mathrm{~Hz}, \mathrm{OCH}_{2} \mathrm{CH}_{3}\right), 63.47$ (d, $J=$ $\left.6.7 \mathrm{~Hz}, \mathrm{OCH}_{2} \mathrm{CH}_{3}\right), 60.30$ (s, CHCHP), 45.80 (s, $\mathrm{NCH}_{2}$ ), 31.49 (d, J $\left.=11.0 \mathrm{~Hz}, \mathrm{CH}_{2} \mathrm{CH}\right), 25.51\left(\mathrm{~s}, \mathrm{NCH}_{2} \mathrm{CH}_{2}\right), 16.48(\mathrm{~d}, J=5.4 \mathrm{~Hz}, 2$ $\left.\times \mathrm{OCH}_{2} \mathrm{CH}_{3}\right) \cdot{ }^{31} \mathrm{P}\left\{/{ }^{1} \mathrm{H}\right\} \mathrm{NMR}(162 \mathrm{MHz}) \delta=16.49$ (s). Minor diastereoisomer $6 \mathbf{b} / 7 \mathbf{b}$ had: ${ }^{1} \mathrm{H}$ NMR $(400 \mathrm{MHz}) \delta=4.80$ (ddd, $J$ $=8.3,3.6,2.1 \mathrm{~Hz}, 1 \mathrm{H}, \mathrm{CHP}), 4.27-4.20\left(\mathrm{~m}, 4 \mathrm{H}, 2 \times \mathrm{OCH}_{2} \mathrm{CH}_{3}\right)$, 4.09-3.99 (m, 1H, CHCHP), 3.66-3.54 (m, 1H, NCHH), 3.25-3.16 $(\mathrm{m}, 1 \mathrm{H}, \mathrm{NCH} H), 2.15-2.06\left(\mathrm{~m}, 1 \mathrm{H}, \mathrm{NCH}_{2} \mathrm{CH}\right), 2.02-1.92(\mathrm{~m}$, $\left.2 \mathrm{H}, \mathrm{CH}_{2} \mathrm{CH}\right), 1.95-1.86\left(\mathrm{~m}, 1 \mathrm{H}, \mathrm{NCH}_{2} \mathrm{CH} H\right), 1.39-1.33$ (m, 6H, 2 $\left.\times \mathrm{OCH}_{2} \mathrm{CH}_{3}\right) \cdot{ }^{13} \mathrm{C} \mathrm{NMR}(101 \mathrm{MHz}) \delta=160.17(\mathrm{~d}, J=9.3 \mathrm{~Hz}, C=$ O), 70.62 (d, $J=172.3 \mathrm{~Hz}, C \mathrm{HP}), 63.83\left(\mathrm{~d}, J=7.0 \mathrm{~Hz}, \mathrm{OCH}_{2} \mathrm{CH}_{3}\right.$ ), $63.15\left(\mathrm{~d}, J=6.8 \mathrm{~Hz}, \mathrm{OCH}_{2} \mathrm{CH}_{3}\right.$ ), 61.01 (s, CHCHP), 45.61 (s, $\mathrm{NCH}_{2}$ ), 26.91 (d, $\left.J=5.7 \mathrm{~Hz}, \mathrm{CH}_{2} \mathrm{CH}\right), 25.70\left(\mathrm{~s}, \mathrm{NCH}_{2} \mathrm{CH}_{2}\right), 16.44$ (br d, $\left.J=5.4 \mathrm{~Hz}, 2 \times \mathrm{OCH}_{2} \mathrm{CH}_{3}\right) .{ }^{31} \mathrm{P}\left\{/{ }^{1} \mathrm{H}\right\} \mathrm{NMR}(162 \mathrm{MHz}) \delta=$ 
14.56 (s). HRMS (ESI) calcd for $\mathrm{C}_{10} \mathrm{H}_{18} \mathrm{NNaO}_{5} \mathrm{P}^{+}\left([\mathrm{M}+\mathrm{Na}]^{+}\right)$: 286.0815, found: 286.0829 .

(2R)-benzyl 2-((diethoxyphosphoryl)fluoromethyl)pyrrolidine-1carboxylate9. Isolated with a yield $8 \%$ as a mixture with $\mathbf{4}$ (Note A1); slightly yellow oil, a mixture of two rotamers $1.46: 1$. Major rotamer had: ${ }^{19} \mathrm{~F}$ NMR $(565 \mathrm{MHz}) \delta=-226.78$ (ddd, $J=78.6$, 46.9, $39.8 \mathrm{~Hz}) .{ }^{31} \mathrm{P}\left\{/{ }^{1} \mathrm{H}\right\}$ NMR $(243 \mathrm{MHz}) \delta=15.71(\mathrm{~d}, J=76.5$ $\mathrm{Hz}$ ). Minor rotamer had: ${ }^{19} \mathrm{~F}$ NMR $(565 \mathrm{MHz}) \delta=-225.83$ (ddd, $J=75.1,47.1,33.8 \mathrm{~Hz}) \cdot{ }^{31} \mathrm{P}\left\{\mid{ }^{1} \mathrm{H}\right\} \mathrm{NMR}(243 \mathrm{MHz}) \delta=15.36(\mathrm{~d}, J$ $=75.7 \mathrm{~Hz})$.

(2S)-tert-butyl 2-((diethoxyphosphoryl)fluoromethyl)pyrrolidine1-carboxylate (10). Observed in a crude reaction mixture as two rotamers $1.08: 1$. Major rotamer had: ${ }^{19} \mathrm{~F}$ NMR $(565 \mathrm{MHz})$ $\delta=-226.96(\mathrm{ddd}, J=79.1,47.0,34.2 \mathrm{~Hz}) .{ }^{31} \mathrm{P}\left\{1{ }^{1} \mathrm{H}\right\}$ NMR $(243$ $\mathrm{MHz}) \delta=16.14(\mathrm{~d}, J=77.6 \mathrm{~Hz})$. Minor rotamer had: ${ }^{19} \mathrm{~F}$ NMR $(565 \mathrm{MHz}) \delta=-226.08(\mathrm{ddd}, J=79.9,47.2,34.4 \mathrm{~Hz}) .{ }^{31} \mathrm{P}\left\{/{ }^{1} \mathrm{H}\right\}$ $\operatorname{NMR}(243 \mathrm{MHz}) \delta=15.94(\mathrm{~d}, J=77.5 \mathrm{~Hz})$.

Benzyl (R)-2-((S)-(diethoxyphosphoryl)((pyridin-2-ylsulfonyl)oxy) methyl)pyrrolidine-1-carboxylate (11a) and benzyl (R)-2-((R)(diethoxyphosphoryl)((pyridin-2-ylsulfonyl)oxy)methyl)pyrrolidine1-carboxylate (11b). Isolated with yield $78 \%$ ( $3: 1$, d.r., Note C1), or $69 \%$ (18: 1 d.r.; Note C2) as a transparent oil, mixture of two diastereoisomers. Major diastereoisomer 11a exist as a mixture of two rotamers $(1.1: 1)$. Major diastereoisomer 11a (major rotamer) had: ${ }^{1} \mathrm{H}$ NMR $(600 \mathrm{MHz}) \delta=8.68(\mathrm{~d}, J=4.0 \mathrm{~Hz}, 1 \mathrm{H}, \mathrm{Ar})$, $7.92(\mathrm{~d}, J=7.9 \mathrm{~Hz}, 1 \mathrm{H}, \mathrm{Ar}), 7.74(\mathrm{~m}, 1 \mathrm{H}, \mathrm{Ar}), 7.47$ (br d, $J=$ $7.6 \mathrm{~Hz}, 1 \mathrm{H}, \mathrm{Ph}), 7.44$ (dd, $J=7.6,4.8 \mathrm{~Hz}, 1 \mathrm{H}, \mathrm{Ar}), 7.41-7.33(\mathrm{~m}$, $3 \mathrm{H}, \mathrm{Ph}), 7.35-7.29(\mathrm{~m}, 1 \mathrm{H}, \mathrm{Ph}), 5.77(\mathrm{dd}, J=11.9,1.7 \mathrm{~Hz}, 1 \mathrm{H}$, CHP), 5.14-5.08 (m, 2H, OCH $\left.\mathrm{O}_{2} \mathrm{Ph}\right), 4.24(\mathrm{dd}, J=9.1,4.8 \mathrm{~Hz}, 1 \mathrm{H}$, CHCHP), 4.18-4.06 (m, 4H, $\left.2 \times \mathrm{OCH}_{2} \mathrm{CH}_{3}\right), 3.28(\mathrm{q}, J=7.7 \mathrm{~Hz}$, $1 \mathrm{H}, \mathrm{NCHH}$ ), 2.96 (ddd, $J=10.4,7.5,5.5 \mathrm{~Hz}, 1 \mathrm{H}, \mathrm{NCH} H$ ), 2.34$2.22(\mathrm{~m}, 1 \mathrm{H}, \mathrm{CH} \mathrm{HCH}), 2.07-1.97(\mathrm{~m}, 1 \mathrm{H}, \mathrm{CH} H \mathrm{CH}), 1,97-1.87$ $\left(\mathrm{m}, 1 \mathrm{H}, \mathrm{NCH}_{2} \mathrm{CHH}\right), 1.78-1.66\left(\mathrm{~m}, 1 \mathrm{H}, \mathrm{NCH}_{2} \mathrm{CH} H\right), 1.33-1.26$ $\left(\mathrm{m}, 3 \mathrm{H}, \mathrm{OCH}_{2} \mathrm{CH}_{3}\right), 1.23\left(\mathrm{t}, J=7.0 \mathrm{~Hz}, 3 \mathrm{H}, \mathrm{OCH}_{2} \mathrm{CH}_{3}\right) .{ }^{13} \mathrm{C} \mathrm{NMR}$ (101 MHz) $\delta=154.92(\mathrm{~s}, C=\mathrm{O}), 154.20(\mathrm{~s}, \mathrm{Ar}), 150.38$ (s, Ar), 138.06, 136.75, 128.63, $127.96(4 \times \mathrm{s}, \mathrm{Ph}), 127.68(\mathrm{~s}, \mathrm{Ar}), 123.36$ (s, Ar), 77.51 (d, $J=159.1 \mathrm{~Hz}, C \mathrm{HP}), 66.86\left(\mathrm{~s}, \mathrm{OCH}_{2} \mathrm{Ph}\right), 63.81$ (d, $\left.J=6.9 \mathrm{~Hz}, \mathrm{OCH}_{2} \mathrm{CH}_{3}\right), 63.47$ (d, $\left.J=6.6 \mathrm{~Hz}, \mathrm{OCH}_{2} \mathrm{CH}_{3}\right), 57.99$ (d, $J=10.2 \mathrm{~Hz}, \mathrm{CHCHP}$ ), 46.59 (s, $\mathrm{NCH}_{2}$ ), 26.04 (s, $\left.\mathrm{CH}_{2} \mathrm{CH}\right), 24.53$ $\left(\mathrm{s}, \mathrm{NCH}_{2} \mathrm{CH}_{2}\right), 16.50\left(\mathrm{~d}, J=5.6 \mathrm{~Hz}, 2 \times \mathrm{OCH}_{2} \mathrm{CH}_{3}\right) \cdot{ }^{31} \mathrm{P}\left\{l^{1} \mathrm{H}\right\}$ NMR $(243 \mathrm{MHz}) \delta=15.15(\mathrm{~s})$. Minor rotamer 11a: ${ }^{1} \mathrm{H}$ NMR $(600$ $\mathrm{MHz}) \delta=8.72(\mathrm{~d}, J=4.4 \mathrm{~Hz}, 1 \mathrm{H}, \mathrm{Ar}), 7.86(\mathrm{~m}, 1 \mathrm{H}, \mathrm{Ar}), 7.74(\mathrm{~d}, J$ $=7.8 \mathrm{~Hz}, 1 \mathrm{H}, \mathrm{Ar}), 7.54(\mathrm{dd}, J=7.7,4.7 \mathrm{~Hz}, 1 \mathrm{H}, \mathrm{Ar}), 7.47(\mathrm{br} \mathrm{d}, J=$ $7.6 \mathrm{~Hz}, 1 \mathrm{H}, \mathrm{Ph}), 7.41-7.33$ (m, 3H, Ph), 7.35-7.29 (m, 1H, Ph), $5.58(\mathrm{dd}, J=12.1,1.7 \mathrm{~Hz}, 1 \mathrm{H}, \mathrm{CHP}), 5.21(\mathrm{~d}, J=12.1 \mathrm{~Hz}, 1 \mathrm{H}$, $\left.\mathrm{OCH}_{2} \mathrm{Ph}\right), 5.14-5.08\left(\mathrm{~m}, 1 \mathrm{H}, \mathrm{OCH}_{2} \mathrm{Ph}\right), 4.20-4.15(\mathrm{~m}, 1 \mathrm{H}$, CHCHP), 4.18-4.06 (m, 2H, $\left.\mathrm{OCH}_{2} \mathrm{CH}_{3}\right), 4.06-3.95(\mathrm{~m}, 2 \mathrm{H}$, $\left.\mathrm{OCH}_{2} \mathrm{CH}_{3}\right), 3.19(\mathrm{dt}, J=10.8,7.4 \mathrm{~Hz}, 1 \mathrm{H}, \mathrm{NCHH}), 2.49$ (ddd, $J=$ $10.7,7.4,5.6 \mathrm{~Hz}, 1 \mathrm{H}, \mathrm{NCH} H), 2.34-2.22(\mathrm{~m}, 1 \mathrm{H}, \mathrm{CHHCH}), 2.07-$ $1.97(\mathrm{~m}, 1 \mathrm{H}, \mathrm{CH} H \mathrm{CH}), 1.78-1.66\left(\mathrm{~m}, 1 \mathrm{H}, \mathrm{NCH}_{2} \mathrm{CHH}\right), 1.64-1.57$ $\left(\mathrm{m}, 1 \mathrm{H}, \mathrm{NCH}_{2} \mathrm{CH} H\right), 1.33-1.26\left(\mathrm{~m}, 6 \mathrm{H}, 2 \times \mathrm{OCH}_{2} \mathrm{CH}_{3}\right) .{ }^{13} \mathrm{C} \mathrm{NMR}$ $(101 \mathrm{MHz}) \delta=154.45(\mathrm{~s}, C=\mathrm{O}), 154.36,150.67,138.38(3 \times \mathrm{s}$, Ar), 136.41, 128.66, 128.11, $127.76(4 \times \mathrm{s}, \mathrm{Ph}), 123.03(\mathrm{~s}, \mathrm{Ar})$, $76.44(\mathrm{~d}, J=160.9 \mathrm{~Hz}, C \mathrm{HP}), 67.56\left(\mathrm{~s}, \mathrm{OCH}_{2} \mathrm{Ph}\right), 64.12(\mathrm{~d}, J=$ $7.2 \mathrm{~Hz}, \mathrm{OCH}_{2} \mathrm{CH}_{3}$ ), $63.32\left(\mathrm{~d}, J=6.4 \mathrm{~Hz}, \mathrm{OCH}_{2} \mathrm{CH}_{3}\right), 57.13(\mathrm{~d}, J=$
$10.7 \mathrm{~Hz}, \mathrm{CHCHP}), 47.02$ (s, $\mathrm{NCH}_{2}$ ), 27.13 (s, $\left.\mathrm{CH}_{2} \mathrm{CH}\right), 23.88$ (s, $\left.\mathrm{NCH}_{2} \mathrm{CH}_{2}\right), 16.43-16.29\left(\mathrm{~m}, 2 \times \mathrm{OCH}_{2} \mathrm{CH}_{3}\right) .{ }^{31} \mathrm{P}\left\{1{ }^{1} \mathrm{H}\right\}$ NMR $(243$ MHz) $\delta=14.72$ (s). HRMS (ESI) calcd for $\mathrm{C}_{22} \mathrm{H}_{29} \mathrm{KN}_{2} \mathrm{O}_{8} \mathrm{PS}+([\mathrm{M}+$ $\mathrm{K}]^{+}$): 551.1014 , found: 551.1022 .

Minor diastereoisomer 11b exist as a mixture of two rotamers $(1: 1)$. Both rotamers $11 \mathrm{~b}$ had: ${ }^{1} \mathrm{H}$ NMR $(600 \mathrm{MHz}) \delta=8.72-$ $8.69(\mathrm{~m}, 1 \mathrm{H}, \mathrm{Ar}), 8.68-8.65(\mathrm{~m}, 1 \mathrm{H}, \mathrm{Ar}), 8.05(\mathrm{~d}, J=7.9 \mathrm{~Hz}, 1 \mathrm{H}$, $\mathrm{Ar}), 7.88-7.79(\mathrm{~m}, 2 \mathrm{H}, \mathrm{Ar}), 7.76(\mathrm{~d}, J=8.0 \mathrm{~Hz}, 1 \mathrm{H}, \mathrm{Ar}), 7.55-7.51$ $(\mathrm{m}, 1 \mathrm{H}, \mathrm{Ph}), 7.49(\mathrm{dd}, J=7.6,4.6 \mathrm{~Hz}, 1 \mathrm{H}, \mathrm{Ar}), 7.46-7.40(\mathrm{~m}, 1 \mathrm{H}$, $\mathrm{Ph}), 7.40(\mathrm{~d}, J=7.4 \mathrm{~Hz}, 1 \mathrm{H}, \mathrm{Ar}), 7.38-7.33(\mathrm{~m}, 2 \mathrm{H}, \mathrm{Ph}), 7.33-7.28$ $(\mathrm{m}, 6 \mathrm{H}, \mathrm{Ph}), 5.34(\mathrm{t}, J=8.8 \mathrm{~Hz}, 1 \mathrm{H}, \mathrm{CHP}), 5.14-5.11(\mathrm{~m}, 1 \mathrm{H}$, CHP), 5.14-5.11 (m, $\left.1 \mathrm{H}, \mathrm{OCH}_{2} \mathrm{Ph}\right), 5.12-5.04\left(\mathrm{~m}, 1 \mathrm{H}, \mathrm{OCH}_{2} \mathrm{Ph}\right)$, 5.00-4.97 (m, $\left.2 \mathrm{H}, \mathrm{OCH}_{2} \mathrm{Ph}\right), 4.40-4.29(\mathrm{~m}, 2 \mathrm{H}, 2 \times \mathrm{CHCHP})$, 4.19-3.95 (m, $\left.8 \mathrm{H}, 4 \times \mathrm{OCH}_{2} \mathrm{CH}_{3}\right), 3.50-3.41\left(\mathrm{~m}, 2 \mathrm{H}, \mathrm{NCH}_{2}\right)$, 3.40-3.34 (m, 1H, NCHH), 3.30-3.22 (m, 1H, NCHH), 2.35-2.30 (m, $\left.2 \mathrm{H}, \mathrm{CH}_{2} \mathrm{CH}\right), 2.06-1.97\left(\mathrm{~m}, 1 \mathrm{H}, \mathrm{CH}_{2} \mathrm{CH}\right), 1.95-1.87(\mathrm{~m}, 2 \mathrm{H}$, $\left.\mathrm{NCH}_{2} \mathrm{CH}_{2}\right), 1.82-1.76\left(\mathrm{~m}, 1 \mathrm{H}, \mathrm{NCH}_{2} \mathrm{CH}_{2}\right), 1.33-1.24(\mathrm{~m}, 9 \mathrm{H}$, $\left.\mathrm{OCH}_{2} \mathrm{CH}_{3}\right), 1.24-1.17$ (m, 3H, $\left.\mathrm{OCH}_{2} \mathrm{CH}_{3}\right) .{ }^{13} \mathrm{C}$ NMR (151 MHz) $\delta=155.24(\mathrm{~s}, C=\mathrm{O}), 154.69$ (s, $C=\mathrm{O}), 154.65,154.51,150.40$, 150.25, 138.26, 138.20 ( $6 \times \mathrm{s}, \mathrm{Ar}), 136.68,136.43,128.66,128.48$, 128.42, 128.19, 128.06, 127.98 ( $8 \times \mathrm{s}, \mathrm{Ph}), 127.84$ (s, Ar), 127.81 (s, Ar), 123.55 (s, Ar), 123.14 (s, Ar), 76.62 (d, J=160.4 Hz, CHP), $76.19(\mathrm{~d}, J=161.6 \mathrm{~Hz}, C \mathrm{HP}), 67.23\left(\mathrm{~s}, \mathrm{OCH}_{2} \mathrm{Ph}\right), 66.86(\mathrm{~s}$, $\left.\mathrm{OCH}_{2} \mathrm{Ph}\right), 64.01\left(\mathrm{~d}, J=6.3 \mathrm{~Hz}, 2 \times \mathrm{OCH}_{2} \mathrm{CH}_{3}\right), 63.27-63.10(\mathrm{~m}, 2$ $\left.\times \mathrm{OCH}_{2} \mathrm{CH}_{3}\right), 57.33(\mathrm{~d}, J=3.5 \mathrm{~Hz}, \mathrm{CHCHP}), 56.54(\mathrm{~d}, J=5.1 \mathrm{~Hz}$, CHCHP), 47.04 (s, $\mathrm{NCH}_{2}$ ), 46.83 (s, $\left.\mathrm{NCH}_{2}\right), 28.13$ (s, $\left.\mathrm{CH}_{2} \mathrm{CH}\right)$, $27.20\left(\mathrm{~s}, \mathrm{CH}_{2} \mathrm{CH}\right), 23.69\left(\mathrm{~s}, \mathrm{NCH}_{2} \mathrm{CH}_{2}\right), 22.91\left(\mathrm{~s}, \mathrm{NCH}_{2} \mathrm{CH}_{2}\right)$, $16.40\left(\mathrm{~d}, J=6.3 \mathrm{~Hz}, 2 \times \mathrm{OCH}_{2} \mathrm{CH}_{3}\right), 16.29(\mathrm{~d}, J=6.0 \mathrm{~Hz}, 2 \times$ $\left.\mathrm{OCH}_{2} \mathrm{CH}_{3}\right) .{ }^{31} \mathrm{P}\left\{/{ }^{1} \mathrm{H}\right\}$ NMR $(243 \mathrm{MHz}) \delta=15.44(\mathrm{~s}), 15.36$ (s).

tert-butyl (S)-2-((R)-(diethoxyphosphoryl)((pyridin-2ylsulfonyl)oxy) methyl)pyrrolidine-1-carboxylate (12a) and tert-butyl (S)-2-((S)(diethoxyphosphoryl)((pyridin-2-ylsulfonyl)oxy)methyl)pyrrolidine-1carboxylate (12b). Isolated with a yield 74\% (74:1 d.r., Note C3) as a slightly yellow oil. Major diastereoisomer 12a exist as a mixture of two rotamers $(1.7: 1)$. Major diastereoisomer 12a (major rotamer) had: ${ }^{1} \mathrm{H}$ NMR $(400 \mathrm{MHz}) \delta=8.77-8.70(\mathrm{~m}, 1 \mathrm{H}$, $\mathrm{Ar}), 7.98-7.87(\mathrm{~m}, 2 \mathrm{H}, \mathrm{Ar}), 7.57-7.51(\mathrm{~m}, 1 \mathrm{H}, \mathrm{Ar}), 5.63(\mathrm{dd}, J=$ $12.3,1.6 \mathrm{~Hz}, 1 \mathrm{H}, \mathrm{CHP}), 4.27-4.12\left(\mathrm{~m}, 4 \mathrm{H}, 2 \times \mathrm{OCH}_{2} \mathrm{CH}_{3}\right), 4.12-$ $4.06(\mathrm{~m}, 1 \mathrm{H}, \mathrm{CHCHP}), 3.05(\mathrm{q}, J=7.9 \mathrm{~Hz}, 1 \mathrm{H}, \mathrm{NCHH}), 2.30-2.15$ $(\mathrm{m}, 2 \mathrm{H}, \mathrm{NCH} H, \mathrm{CHHCH}), 2.04-1.87(\mathrm{~m}, 1 \mathrm{H}, \mathrm{CH} H \mathrm{CH}), 1.72-1.52$ $\left(\mathrm{m}, 2 \mathrm{H}, \mathrm{NCH}_{2} \mathrm{CH}_{2}\right), 1.52\left(\mathrm{br} \mathrm{s}, 9 \mathrm{H}, \mathrm{C}\left(\mathrm{CH}_{3}\right)_{3}\right), 1.39-1.29(\mathrm{~m}, 6 \mathrm{H}, 2$ $\left.\times \mathrm{OCH}_{2} \mathrm{CH}_{3}\right) \cdot{ }^{13} \mathrm{C}$ NMR $(101 \mathrm{MHz}) \delta=154.58(\mathrm{~s}, \mathrm{C}=\mathrm{O}), 153.69$ (s, Ar), 150.64 (s, Ar), 138.38 (s, Ar), 127.67 (s, Ar), 122.96 (s, Ar), $80.49\left(\mathrm{~s}, C\left(\mathrm{CH}_{3}\right)_{3}\right), 78.06(\mathrm{~d}, J=140.2 \mathrm{~Hz}, C \mathrm{HP}), 64.12(\mathrm{~d}, J=$ $\left.7.3 \mathrm{~Hz}, \mathrm{OCH}_{2} \mathrm{CH}_{3}\right), 63.14\left(\mathrm{~d}, J=6.6 \mathrm{~Hz}, \mathrm{OCH}_{2} \mathrm{CH}_{3}\right), 57.14(\mathrm{~d}, J=$ $11.0 \mathrm{~Hz}, \mathrm{CHCHP}), 46.25\left(\mathrm{~s}, \mathrm{NCH}_{2}\right), 28.52\left(\mathrm{~s}, \mathrm{C}\left(\mathrm{CH}_{3}\right)_{3}\right), 27.01(\mathrm{~s}$, $\left.\mathrm{CH}_{2} \mathrm{CH}\right), 23.83\left(\mathrm{~s}, \mathrm{NCH}_{2} \mathrm{CH}_{2}\right), 16.46(\mathrm{~d}, J=5.9 \mathrm{~Hz}, 2 \times$ $\left.\mathrm{OCH}_{2} \mathrm{CH}_{3}\right) .{ }^{31} \mathrm{P}\left\{/{ }^{1} \mathrm{H}\right\}$ NMR $(162 \mathrm{MHz}) \delta=15.38(\mathrm{~s})$. Minor rotamer 12a had: ${ }^{1} \mathrm{H}$ NMR $(400 \mathrm{MHz}) \delta=8.77-8.70(\mathrm{~m}, 1 \mathrm{H}, \mathrm{Ar})$, $8.01(\mathrm{~d}, J=7.9 \mathrm{~Hz}, 1 \mathrm{H}, \mathrm{Ar}), 7.98-7.87(\mathrm{~m}, 1 \mathrm{H}, \mathrm{Ar}), 7.57-7.51(\mathrm{~m}$, $1 \mathrm{H}, \mathrm{Ar}), 5.75(\mathrm{~d}, J=11.7 \mathrm{~Hz}, 1 \mathrm{H}, \mathrm{CHP}), 4.27-4.12(\mathrm{~m}, 1 \mathrm{H}$, CHCHP), $4.12-4.06\left(\mathrm{~m}, 2 \mathrm{H}, \mathrm{OCH}_{2} \mathrm{CH}_{3}\right), 4.06-3.97(\mathrm{~m}, 2 \mathrm{H}$, $\left.\mathrm{OCH}_{2} \mathrm{CH}_{3}\right), 3.29-3.17(\mathrm{~m}, 1 \mathrm{H}, \mathrm{NCHH}), 3.05(\mathrm{q}, J=7.9 \mathrm{~Hz}, 1 \mathrm{H}$, $\mathrm{NCH} H), 2.30-2.15(\mathrm{~m}, 1 \mathrm{H}, \mathrm{CHHCH}), 2.04-1.87(\mathrm{~m}, 3 \mathrm{H}, \mathrm{CH} H \mathrm{CH}$, $\mathrm{NCH}_{2} \mathrm{CH}_{2}$ ), 1.47 (br s, 9H, C( $\left.\left(\mathrm{CH}_{3}\right)_{3}\right), 1.27$ (br t, $J=7.1 \mathrm{~Hz}, 3 \mathrm{H}$, $\left.\mathrm{OCH}_{2} \mathrm{CH}_{3}\right), 1.23\left(\mathrm{br} \mathrm{t}, J=6.8 \mathrm{~Hz}, 3 \mathrm{H}, \mathrm{OCH}_{2} \mathrm{CH}_{3}\right) .{ }^{13} \mathrm{C}$ NMR $(101$ 
$\mathrm{MHz}) \delta=154.76$ (s, $C=\mathrm{O}), 153.69$ (s, Ar), 150.30 (s, Ar), 138.05 (s, Ar), $127.63(\mathrm{~s}, \mathrm{Ar}), 123.40(\mathrm{~s}, \mathrm{Ar}), 79.79\left(\mathrm{~s}, C\left(\mathrm{CH}_{3}\right)_{3}\right), 76.64(\mathrm{~d}, J$ $=144.5 \mathrm{~Hz}, C \mathrm{HP}), 63.42\left(\mathrm{~d}, J=6.9 \mathrm{~Hz}, \mathrm{OCH}_{2} \mathrm{CH}_{3}\right), 63.37(\mathrm{~d}, J=$ $5.6 \mathrm{~Hz}, \mathrm{OCH}_{2} \mathrm{CH}_{3}$ ), 57.38 (d, $\left.J=9.9 \mathrm{~Hz}, C \mathrm{HCHP}\right), 46.75$ (s, $\left.\mathrm{NCH}_{2}\right), 28.63\left(\mathrm{~s}, \mathrm{C}\left(\mathrm{CH}_{3}\right)_{3}\right), 26.04\left(\mathrm{~s}, \mathrm{CH}_{2} \mathrm{CH}\right), 24.50$ (s, $\mathrm{NCH}_{2} \mathrm{CH}_{2}$ ), 16.57 (d, $\left.J=5.8 \mathrm{~Hz}, 2 \times \mathrm{OCH}_{2} \mathrm{CH}_{3}\right) .{ }^{31} \mathrm{P}\left\{/{ }^{1} \mathrm{H}\right\} \mathrm{NMR}$ $(162 \mathrm{MHz}) \delta=15.55(\mathrm{~s})$. Minor diastereoisomer $12 \mathrm{~b}$ was present in crude reaction mixture as a mixture of two rotamers $3.9: 1$. Major rotamer had: ${ }^{31} \mathrm{P}\left\{/{ }^{1} \mathrm{H}\right\}$ NMR $(243 \mathrm{MHz}) \delta=15.98(\mathrm{~s})$. Minor rotamer had: ${ }^{31} \mathrm{P}\left\{/{ }^{1} \mathrm{H}\right\}$ NMR (243 MHz) $\delta=15.89(\mathrm{~s})$. HRMS (ESI) calcd for $\mathrm{C}_{19} \mathrm{H}_{32} \mathrm{~N}_{2} \mathrm{O}_{8} \mathrm{PS}^{+}\left([\mathrm{M}+\mathrm{H}]^{+}\right)$: 479.1611, found: 479.1606 .

Diethyl ((2S,3R)-1-benzyl-3-fluoropiperidin-2-yl)phosphonate (13a) and diethyl ((2S,3S)-1-benzyl-3-fluoropiperidin-2-yl) phosphonate (13b). Isolated with a yield 59\% (6.2: 1 d.r., Note A4) or $74 \%$ (5.7 : 1, d.r., Note B1) or 30\% (99: 1, d.r., Note C4), as slightly yellow oil, mixture of two diastereoisomers. Major diastereoisomer 13a had: ${ }^{1} \mathrm{H}$ NMR $(600 \mathrm{MHz}) \delta=7.42-7.37(\mathrm{~m}$, $3 \mathrm{H}, \mathrm{Ph}), 7.32-7.27(\mathrm{~m}, 2 \mathrm{H}, \mathrm{Ph}), 4.15-4.07(\mathrm{~m}, 4 \mathrm{H}, 2 \times$ $\mathrm{OCH}_{2} \mathrm{CH}_{3}$ ), 4.06 (dd, $\left.J=14.4,4.8 \mathrm{~Hz}, 1 \mathrm{H}, \mathrm{NCHHPh}\right), 3.89$ (d, $J=$ $14.0 \mathrm{~Hz}, 1 \mathrm{H}, \mathrm{NCH} H \mathrm{Ph}$ ), 3.34 (t, $J=14.5 \mathrm{~Hz}, 1 \mathrm{H}, \mathrm{CHHCHF}), 3.30$ (d, $J=9.0 \mathrm{~Hz}, 1 \mathrm{H}, \mathrm{CHP}$ ), 3.26 (ddd, $J=26.1,14.2,2.0 \mathrm{~Hz}, 1 \mathrm{H}$, $\mathrm{CH} \mathrm{HCHF}$ ), 2.97-2.92 (m, 1H, $\mathrm{NCHH}$ ), 2.62 (br dd, $J=12.1$, $3.5 \mathrm{~Hz}, 1 \mathrm{H}, \mathrm{NCHH}), 2.56-2.48\left(\mathrm{~m}, 1 \mathrm{H}, \mathrm{NCH}_{2} \mathrm{CHH}\right), 1.75(\mathrm{br} \mathrm{d}, J=$ $\left.13.0 \mathrm{~Hz}, 1 \mathrm{H}, \mathrm{NCH}_{2} \mathrm{CHH}\right), 1.31\left(\mathrm{t}, J=7.1 \mathrm{~Hz}, 3 \mathrm{H}, \mathrm{OCH}_{2} \mathrm{CH}_{3}\right), 1.26$ $\left(\mathrm{t}, J=7.1 \mathrm{~Hz}, 3 \mathrm{H}, \mathrm{OCH}_{2} \mathrm{CH}_{3}\right) .{ }^{13} \mathrm{C} \mathrm{NMR}(151 \mathrm{MHz}) \delta=139.90$, 128.46, 128.25, $127.14(4 \times \mathrm{s}, \mathrm{Ph}), 95.87(\mathrm{dd}, J=177.6,3.1 \mathrm{~Hz}$, $C \mathrm{HF}$ ), 64.40 (dd, $J=125.5,25.9 \mathrm{~Hz}, C \mathrm{HP}), 61.79$ (dd, $J=7.3$, $\left.4.1 \mathrm{~Hz}, \mathrm{OCH}_{2} \mathrm{CH}_{3}\right) 60.78$ (d, $\left.J=7.2 \mathrm{~Hz}, \mathrm{OCH}_{2} \mathrm{CH}_{3}\right), 60.22(\mathrm{~m}$, $\mathrm{CH}_{2} \mathrm{Ph}$ ), 45.86 (d, $J=3.2 \mathrm{~Hz}, \mathrm{NCH}_{2}$ ), 43.28 (dd, $J=21.8,10.0 \mathrm{~Hz}$, $\mathrm{CH}_{2} \mathrm{CHF}$ ), 30.20 (d, $J=20.5 \mathrm{~Hz}, \mathrm{NCH}_{2} \mathrm{CH}_{2}$ ), 16.64 (d, $J=5.8 \mathrm{~Hz}$, $\mathrm{OCH}_{2} \mathrm{CH}_{3}$ ), 16.54 (d, $\left.J=5.7 \mathrm{~Hz}, \mathrm{OCH}_{2} \mathrm{CH}_{3}\right) .{ }^{19} \mathrm{~F} \mathrm{NMR}(565 \mathrm{MHz})$ $\delta=-146.12$ (br dt, $J=27.4,14.2 \mathrm{~Hz}) .{ }^{19} \mathrm{~F}\left\{/{ }^{1} \mathrm{H}\right\} \mathrm{NMR}(565 \mathrm{MHz})$ $\delta=-146.11$ (d, $J=3.7 \mathrm{~Hz}) .{ }^{31} \mathrm{P}\left\{/{ }^{1} \mathrm{H}\right\} \operatorname{NMR}(243 \mathrm{MHz}) \delta=26.96$ (d, $J=4.1 \mathrm{~Hz})$.

Minor diastereoisomer 13b had: ${ }^{1} \mathrm{H}$ NMR (600 MHz) $\delta=$ 7.37-7.32 (m, 3H, Ph), 7.31-7.29 (m, 2H, Ph), 4.27-4.23 (m, 1H, $\left.\mathrm{OCH}_{\mathrm{HCH}}\right)$, 4.22-4.18 (m, 1H, $\left.\mathrm{OCH} \mathrm{HCH}_{3}\right), 4.18-4.07(\mathrm{~m}, 4 \mathrm{H}$, $\left.\mathrm{OCH}_{2} \mathrm{CH}_{3}, \mathrm{NCH}_{2} \mathrm{Ph}\right) 3.43$ (dd, $J=21.9,13.5 \mathrm{~Hz}, 1 \mathrm{H}, \mathrm{CHP}$ ), 3.19 (d, $J=14.6 \mathrm{~Hz}, 1 \mathrm{H}, \mathrm{NCHH}), 3.16$ (d, $J=13.1 \mathrm{~Hz}, 1 \mathrm{H}, \mathrm{CHHCHF}$ ), 3.09 (dd, $J=37.3,14.2 \mathrm{~Hz}, 1 \mathrm{H}, \mathrm{CH} H \mathrm{CHF}$ ), 2.69 (br d, $J=13.5 \mathrm{~Hz}$, $1 \mathrm{H}, \mathrm{NCH} H), 2.08$ (dtd, $J=43.5,13.6,4.8 \mathrm{~Hz}, 1 \mathrm{H}, \mathrm{NCH}_{2} \mathrm{CHH}$ ), 1.92-1.86 (m, 1H, $\left.\mathrm{NCH}_{2} \mathrm{CH} H\right), 1.38(\mathrm{t}, J=7.1 \mathrm{~Hz}, 3 \mathrm{H}$, $\left.\mathrm{OCH}_{2} \mathrm{CH}_{3}\right), 1.32\left(\mathrm{t}, J=7.0 \mathrm{~Hz}, 3 \mathrm{H}, \mathrm{OCH}_{2} \mathrm{CH}_{3}\right) .{ }^{13} \mathrm{C}$ NMR (151 $\mathrm{MHz}) \delta=135.63,128.96,128.27,128.01(4 \times \mathrm{s}, \mathrm{Ph}), 95.95(\mathrm{dd}, J$ $=180.3,26.3 \mathrm{~Hz}, C \mathrm{HF}$ ), 65.36 (dd, $J=146.2,21.4 \mathrm{~Hz}, C H \mathrm{H})$, $63.12\left(\mathrm{~d}, J=7.2 \mathrm{~Hz}, \mathrm{OCH}_{2} \mathrm{CH}_{3}\right), 61.25$ (d, $J=7.7 \mathrm{~Hz}, \mathrm{OCH}_{2} \mathrm{CH}_{3}$ ), 60.56 (dd, $\left.J=12.0,3.6 \mathrm{~Hz}, \mathrm{CH}_{2} \mathrm{Ph}\right), 46.02\left(\mathrm{~s}, \mathrm{NCH}_{2}\right), 44.34$ (d, $J=$ $20.8 \mathrm{~Hz}, \mathrm{CH}_{2} \mathrm{CHF}$ ), 29.74 (d, $J=22.4 \mathrm{~Hz}, \mathrm{NCH}_{2} \mathrm{CH}_{2}$ ), 16.75 (d, $J$ $\left.=6.2 \mathrm{~Hz}, \mathrm{OCH}_{2} \mathrm{CH}_{3}\right), 16.47\left(\mathrm{~d}, J=6.2 \mathrm{~Hz}, \mathrm{OCH}_{2} \mathrm{CH}_{3}\right) .{ }^{19} \mathrm{~F} \mathrm{NMR}$ $(565 \mathrm{MHz}) \delta=-144.73$ to $-145.09(\mathrm{~m}) .{ }^{31} \mathrm{P}\left\{/{ }^{1} \mathrm{H}\right\}(243 \mathrm{MHz}) \delta=$ $23.22(\mathrm{~d}, J=63.4 \mathrm{~Hz})$. HRMS (ESI) calcd for $\mathrm{C}_{16} \mathrm{H}_{26} \mathrm{FNO}_{3} \mathrm{P}^{+}([\mathrm{M}+$ $\left.\mathrm{H}]^{+}\right)$: 330.1629 , found: 330.1626 , major peak: $\mathrm{C}_{23} \mathrm{H}_{32} \mathrm{FNO}_{3} \mathrm{P}^{+}([\mathrm{M}$ $\left.+\mathrm{Bn}]^{+}\right):$420.2098, found: 420.2095 .

Diethyl (((S)-1-benzylpyrrolidin-2-yl)fluoromethyl)phosphonate (14). Observed in a crude reaction mixture. Diagnostic signals:
${ }^{19} \mathrm{~F} \mathrm{NMR}(565 \mathrm{MHz}) \delta=-207.63(\mathrm{dd}, J=81.6,44.8 \mathrm{~Hz}) \cdot{ }^{31} \mathrm{P}\left\{/{ }^{1} \mathrm{H}\right\}$ $(243 \mathrm{MHz}) \delta=16.51(\mathrm{~d}, J=82.0 \mathrm{~Hz})$.

Diethyl (1S,7aS)-5,5-dimethyl-3-oxotetrahydro-1H-oxazolo[3,4c]oxazol-1-ylphosphonate (17). Isolated with a yield $32 \%$ (Note A5) or 40\% (Note A6) as a slightly yellow oil. Compound 17 had: ${ }^{1} \mathrm{H}$ NMR $(400 \mathrm{MHz}) \delta=4.54(\mathrm{ddt}, J=15.3,7.3,6.2 \mathrm{~Hz}, 1 \mathrm{H}, \mathrm{CHP})$, 4.38 (dd, $J=6.2,1.5 \mathrm{~Hz}, 1 \mathrm{H}, \mathrm{CHCHP}), 4.30-4.21(\mathrm{~m}, 4 \mathrm{H}, 2 \times$ $\left.\mathrm{OCH}_{2} \mathrm{CH}_{3}\right), 4.18(\mathrm{dd}, J=8.6,6.2 \mathrm{~Hz}, 1 \mathrm{H}, \mathrm{OCHH}), 3.67(\mathrm{dd}, J=$ 8.6, $7.4 \mathrm{~Hz}, 1 \mathrm{H}, \mathrm{OCH} H), 1.72\left(\mathrm{~s}, 3 \mathrm{H}, \mathrm{C}\left(\mathrm{CH}_{3}\right)\right), 1.45(\mathrm{~s}, 3 \mathrm{H}$, $\left.\mathrm{C}\left(\mathrm{CH}_{3}\right)\right), 1.37\left(\mathrm{t}, J=7.0 \mathrm{~Hz}, 6 \mathrm{H}, 2 \times \mathrm{OCH}_{2} \mathrm{CH}_{3}\right) .{ }^{13} \mathrm{C}$ NMR (101 $\mathrm{MHz}) \delta=155.91(\mathrm{~d}, J=6.4 \mathrm{~Hz}, C=\mathrm{O}), 95.45\left(\mathrm{~s}, C\left(\mathrm{CH}_{3}\right)_{2}\right), 71.82$ (d, $J=176.3 \mathrm{~Hz}, C \mathrm{HP}), 68.73\left(\mathrm{~d}, J=10.6 \mathrm{~Hz}, \mathrm{OCH}_{2}\right), 64.29$ (d, $J=$ $\left.6.9 \mathrm{~Hz}, \mathrm{OCH}_{2} \mathrm{CH}_{3}\right), 63.81$ (d, $\left.J=6.7 \mathrm{~Hz}, \mathrm{OCH}_{2} \mathrm{CH}_{3}\right), 59.56$ (s, CHCHP), $27.48\left(\mathrm{~s}, \mathrm{C}\left(\mathrm{CH}_{3}\right)\right), 23.35$ (s, $\left.\mathrm{C}\left(\mathrm{CH}_{3}\right)\right), 16.64$ (d, $J=$ $\left.5.3 \mathrm{~Hz}, \mathrm{OCH}_{2} \mathrm{CH}_{3}\right), 16.59\left(\mathrm{~d}, J=5.7 \mathrm{~Hz}, \mathrm{OCH}_{2} C_{3}\right) .{ }^{31} \mathrm{P}\left\{/{ }^{1} \mathrm{H}\right\}$ NMR (162 MHz) $\delta=15.70(\mathrm{~s})$. HRMS (ESI) calcd for $\mathrm{C}_{11} \mathrm{H}_{20^{-}}$ $\mathrm{NNaO}_{6} \mathrm{P}^{+}\left([\mathrm{M}+\mathrm{Na}]^{+}\right)$: 316.0920, found: 316.0929.

(2S,3S)-benzyl 2-(diethoxyphosphoryl)-3-(hydroxymethyl)aziridine1-carboxylate (18). Isolated with a yield $17 \%$ (Note A5) as a slightly yellow oil. Major rotamer had: ${ }^{1} \mathrm{H}$ NMR $(400 \mathrm{MHz}) \delta=$ 7.43-7.34 (m, 5H, Ph), 5.21 (d, $J=12.1 \mathrm{~Hz}, 1 \mathrm{H}, \mathrm{CHHPh}), 5.17$ (d, $J=12.1 \mathrm{~Hz}, 1 \mathrm{H}, \mathrm{CH} H \mathrm{Ph}), 4.24-4.10\left(\mathrm{~m}, 5 \mathrm{H}, 2 \times \mathrm{OCH}_{2} \mathrm{CH}_{3}\right.$, $\mathrm{OCHH}), 3.73(\mathrm{dd}, J=13.0,4.1 \mathrm{~Hz}, 1 \mathrm{H}, \mathrm{OCH} H), 3.04(\mathrm{dtd}, J=7.7$, 4.0, $2.3 \mathrm{~Hz}, 1 \mathrm{H}, C \mathrm{HCP}), 2.76-2.70$ (m, 1H, CHP), 1.36-1.30 (m, $\left.6 \mathrm{H}, 2 \times \mathrm{OCH}_{2} \mathrm{CH}_{3}\right) \cdot{ }^{13} \mathrm{C} \mathrm{NMR}(151 \mathrm{MHz}) \delta=160.98(\mathrm{~d}, J=$ $7.1 \mathrm{~Hz}, C=\mathrm{O}), 135.42,128.77,128.73,128.59(4 \times \mathrm{s}, \mathrm{Ph}), 68.99$ (s, $\left.\mathrm{CH}_{2} \mathrm{Ph}\right), 63.41$ (d, $\left.J=6.2 \mathrm{~Hz}, \mathrm{OCH}_{2} \mathrm{CH}_{3}\right), 62.92(\mathrm{~d}, J=6.1 \mathrm{~Hz}$, $\mathrm{OCH}_{2} \mathrm{CH}_{3}$ ), $59.24\left(\mathrm{~s}, \mathrm{OCH}_{2}\right.$ ), 41.84 (d, $\left.J=3.2 \mathrm{~Hz}, C H C P\right), 31.84$ (d, $J=201.2 \mathrm{~Hz}, C \mathrm{HP}$ ), 16.55 (d, $J=6.6 \mathrm{~Hz}, \mathrm{OCH}_{2} \mathrm{CH}_{3}$ ), 16.48 (d, $\left.J=6.8 \mathrm{~Hz}, \mathrm{OCH}_{2} \mathrm{CH}_{3}\right) .{ }^{31} \mathrm{P} \mathrm{NMR}\left\{/{ }^{1} \mathrm{H}\right\} \mathrm{NMR}(162 \mathrm{MHz}) \delta=18.43$ (s). Minor rotamer (traces) had: ${ }^{31} \mathrm{P}\left\{/{ }^{1} \mathrm{H}\right\} \mathrm{NMR}(162 \mathrm{MHz}) \delta=$ 19.2 (s). HRMS (ESI) calcd for $\mathrm{C}_{15} \mathrm{H}_{23} \mathrm{NO}_{6} \mathrm{P}^{+}\left([\mathrm{M}+\mathrm{H}]^{+}\right)$: 344.1258, found: 344.1252 .

(2S,3S)-tert-butyl 2-(diethoxyphosphoryl)-3-(hydroxymethyl) aziridine-1-carboxylate (19). Isolated with a yield 56\% (Note A6) or $24 \%$ (Note A7) or $5 \%$ (Note A8) as a transparent oil. Major rotamer had: ${ }^{1} \mathrm{H}$ NMR $(400 \mathrm{MHz}) \delta=4.21-4.14(\mathrm{~m}, 4 \mathrm{H}, 2 \times$ $\mathrm{OCH}_{2} \mathrm{CH}_{3}$ ), 4.08 (br d, $J=12.8 \mathrm{~Hz}, 1 \mathrm{H}, \mathrm{OCHH}$ ), 3.67 (dd, $J=$ 12.9, $5.0 \mathrm{~Hz}, 1 \mathrm{H}, \mathrm{OCH} H$ ), 2.96 (dddd, $J=7.5,5.0,3.5,2.6 \mathrm{~Hz}, 1 \mathrm{H}$, CHCHP), 2.60 (dd, $J=18.7,3.6 \mathrm{~Hz}, 1 \mathrm{H}, \mathrm{CHP}$ ), 1.47 (s, 9H, $\left.\mathrm{C}\left(\mathrm{CH}_{3}\right)_{3}\right), 1.35\left(\mathrm{t}, J=7.1 \mathrm{~Hz}, 3 \mathrm{H}, \mathrm{OCH}_{2} \mathrm{CH}_{3}\right), 1.34(\mathrm{t}, J=7.1 \mathrm{~Hz}$, $\left.3 \mathrm{H}, \mathrm{OCH}_{2} \mathrm{CH}_{3}\right) \cdot{ }^{13} \mathrm{C} \mathrm{NMR}(75 \mathrm{MHz}) \delta=159.79(\mathrm{~d}, J=6.9 \mathrm{~Hz}, C=$ O), $82.61\left(\mathrm{~s}, C\left(\mathrm{CH}_{3}\right)_{3}\right), 63.29\left(\mathrm{~d}, J=6.4 \mathrm{~Hz}, \mathrm{OCH}_{2} \mathrm{CH}_{3}\right), 62.81(\mathrm{~d}, J$ $\left.=6.0 \mathrm{~Hz}, \mathrm{OCH}_{2} \mathrm{CH}_{3}\right), 60.16\left(\mathrm{~s}, \mathrm{OCH}_{2}\right), 41.78(\mathrm{~d}, J=3.3 \mathrm{~Hz}$, CHCHP), 31.94 (d, $J=201.4 \mathrm{~Hz}, \mathrm{CHP}), 28.00\left(\mathrm{~s}, \mathrm{C}\left(\mathrm{CH}_{3}\right)_{3}\right), 16.54$ (br d, $\left.J=6.2 \mathrm{~Hz}, 2 \times \mathrm{OCH}_{2} \mathrm{CH}_{3}\right) .{ }^{31} \mathrm{P}\left\{/{ }^{1} \mathrm{H}\right\} \mathrm{NMR}(162 \mathrm{MHz}) \delta=$ 18.89 (s). Minor rotamer had: ${ }^{1} \mathrm{H}$ NMR $(400 \mathrm{MHz}) \delta=4.23-4.14$ (m, $\left.4 \mathrm{H}, 2 \times \mathrm{OCH}_{2} \mathrm{CH}_{3}\right), 4.14-4.09(\mathrm{~m}, 1 \mathrm{H}, \mathrm{OCHH}), 3.64(\mathrm{dt}, J=$ 12.6, $4.8 \mathrm{~Hz}, 1 \mathrm{H}, \mathrm{OCH} H$ ), 2.98 (dddd, $J=7.6,5.7,3.6,2.4 \mathrm{~Hz}, 1 \mathrm{H}$, CHCHP), 2.60 (dd, $J=18.4,3.6 \mathrm{~Hz}, 1 \mathrm{H}, \mathrm{CHP}), 2.30$ (t, $J=6.7 \mathrm{~Hz}$, $1 \mathrm{H}, \mathrm{OH}), 1.48\left(\mathrm{~s}, 9 \mathrm{H}, \mathrm{C}\left(\mathrm{CH}_{3}\right)_{3}\right), 1.36(\mathrm{t}, J=7.1 \mathrm{~Hz}, 6 \mathrm{H}, 2 \times$ $\left.\mathrm{OCH}_{2} \mathrm{CH}_{3}\right) .{ }^{13} \mathrm{C} \mathrm{NMR}(101 \mathrm{MHz}) \delta=159.88(\mathrm{~d}, J=6.9 \mathrm{~Hz}, \mathrm{C}=\mathrm{O})$, $82.77\left(\mathrm{~s}, C\left(\mathrm{CH}_{3}\right)_{3}\right), 63.32\left(\mathrm{~d}, J=6.4 \mathrm{~Hz}, \mathrm{OCH}_{2} \mathrm{CH}_{3}\right), 62.81(\mathrm{~d}, J=$ $\left.6.2 \mathrm{~Hz}, \mathrm{OCH}_{2} \mathrm{CH}_{3}\right), 60.58\left(\mathrm{~d}, J=2.0 \mathrm{~Hz}, \mathrm{OCH}_{2}\right), 41.70(\mathrm{~d}, J=$ $3.3 \mathrm{~Hz}, C \mathrm{HCHP}$ ), 32.11 (d, $J=201.9 \mathrm{~Hz}, \mathrm{CHP}), 28.03\left(\mathrm{~s}, \mathrm{C}\left(\mathrm{CH}_{3}\right)_{3}\right)$, 
$16.58\left(\mathrm{~d}, J=6.1 \mathrm{~Hz}, \mathrm{OCH}_{2} \mathrm{CH}_{3}\right), 16.57$ (d, $J=6.1 \mathrm{~Hz}, \mathrm{OCH}_{2} \mathrm{CH}_{3}$ ). ${ }^{31} \mathrm{P}\left\{/{ }^{1} \mathrm{H}\right\}$ NMR (162 MHz) $\delta=18.74$ (s). HRMS (ESI) calcd for $\mathrm{C}_{12} \mathrm{H}_{24} \mathrm{NNaO}_{6} \mathrm{P}+\left([\mathrm{M}+\mathrm{Na}]^{+}\right)$: 332.1233, found: 332.1240 .

Diethyl ((4S,5S)-4-(hydroxymethyl)-2-oxooxazolidin-5-yl) phosphonate (21). Isolated with a yield $38 \%$ (Note A7) as slightly pink oil. Compound 21 had: ${ }^{1} \mathrm{H}$ NMR (400 MHz) $\delta=$ 7.12 (br s, 1H, NH), 4.63 (d, $J=5.8 \mathrm{~Hz}, 1 \mathrm{H}, \mathrm{CHP}), 4.25-4.16$ (m, $4 \mathrm{H}, 2 \times \mathrm{OCH}_{2} \mathrm{CH}_{3}$ ), 4.11 (ddt, $J=18.4,5.8,3.7 \mathrm{~Hz}, 1 \mathrm{H}, \mathrm{CHCHP}$ ), $3.71(\mathrm{dd}, J=12.0,3.2 \mathrm{~Hz}, 1 \mathrm{H}, \mathrm{OCHH}), 3.54(\mathrm{dd}, J=12.0,4.3 \mathrm{~Hz}$, $1 \mathrm{H}, \mathrm{OCH} H), 1.34\left(\mathrm{t}, J=7.0 \mathrm{~Hz}, 6 \mathrm{H}, 2 \times \mathrm{OCH}_{2} \mathrm{CH}_{3}\right) \cdot{ }^{13} \mathrm{C} \mathrm{NMR}$ $(101 \mathrm{MHz}) \delta=159.00(\mathrm{~d}, J=4.4 \mathrm{~Hz}, C=\mathrm{O}), 71.74(\mathrm{~d}, J=$ $173.3 \mathrm{~Hz}, C \mathrm{HP}$ ), 64.34 (d, $J=6.9 \mathrm{~Hz}, \mathrm{OCH}_{2} \mathrm{CH}_{3}$ ), 63.86 (d, $J=$ $6.9 \mathrm{~Hz}, \mathrm{OCH}_{2} \mathrm{CH}_{3}$ ), 63.04 (d, $\left.J=10.2 \mathrm{~Hz}, \mathrm{OCH}_{2}\right), 55.35$ (s, $C \mathrm{HCHP}$ ), 16.55 (d, $J=5.0 \mathrm{~Hz}, \mathrm{OCH}_{2} C_{3}$ ), 16.47 (d, $J=5.0 \mathrm{~Hz}$, $\mathrm{OCH}_{2} \mathrm{CH}_{3}$ ). ${ }^{31} \mathrm{P}\left\{/{ }^{1} \mathrm{H}\right\}$ NMR (121 MHz) $\delta=17.82$ (s). HRMS (ESI) calcd for $\mathrm{C}_{8} \mathrm{H}_{16} \mathrm{NNaO}_{6} \mathrm{P}^{+}\left([\mathrm{M}+\mathrm{Na}]^{+}\right)$: 278.0564, found: 278.0564 .

Diethyl ((4S,5S)-4-(fluoromethyl)-2-oxooxazolidin-5-yl)phosphonate (22a) and diethyl ((4S,5R)-4-(fluoromethyl)-2-oxooxazolidin-5-yl) phosphonate (22b). Isolated with a yield 37\% (Note A8) as transparent oil, a mixture of two invertomers 12.6 : 1. Major invertomer had: ${ }^{1} \mathrm{H}$ NMR $(600 \mathrm{MHz}) \delta=6.39(\mathrm{~s}, 1 \mathrm{H}, \mathrm{NH}), 4.51(\mathrm{~d}, J=$ $6.1 \mathrm{~Hz}, 1 \mathrm{H}, \mathrm{CHP}$ ), 4.50 (ddd, $J=47.1,10.1,3.4 \mathrm{~Hz}, 1 \mathrm{H}, \mathrm{CHHF}$ ), 4.40 (ddd, $J=46.6,9.7,4.7 \mathrm{~Hz}, 1 \mathrm{H}, C \mathrm{H} H F), 4.29-4.26(\mathrm{~m}, 1 \mathrm{H}$, CHCHP), 4.26-4.21 (m, 4H, $\left.2 \times \mathrm{OCH}_{2} \mathrm{CH}_{3}\right), 1.37(\mathrm{t}, J=7.1 \mathrm{~Hz}$, $\left.6 \mathrm{H}, 2 \times \mathrm{OCH}_{2} \mathrm{CH}_{3}\right) .{ }^{13} \mathrm{C}$ NMR $(151 \mathrm{MHz}) \delta=157.82(\mathrm{~d}, J=$ $4.7 \mathrm{~Hz}, C=\mathrm{O}$ ), 82.82 (dd, $J=176.6,10.2 \mathrm{~Hz}, C \mathrm{H}_{2} \mathrm{~F}$ ), 70.85 (dd, $J$ $=174.6,6.1 \mathrm{~Hz}, C \mathrm{HP}), 64.44\left(\mathrm{~d}, J=7.0 \mathrm{~Hz}, \mathrm{OCH}_{2} \mathrm{CH}_{3}\right), 63.92(\mathrm{~d}, J$ $\left.=6.8 \mathrm{~Hz}, \mathrm{OCH}_{2} \mathrm{CH}_{3}\right), 53.44(\mathrm{~d}, J=20.7 \mathrm{~Hz}, \mathrm{NCH}), 16.59(\mathrm{~d}, J=$ $\left.5.7 \mathrm{~Hz}, \mathrm{OCH}_{2} \mathrm{CH}_{3}\right), 16.54\left(\mathrm{~d}, J=5.9 \mathrm{~Hz}, \mathrm{OCH}_{2} \mathrm{CH}_{3}\right) .{ }^{19} \mathrm{~F}$ NMR $(565 \mathrm{MHz}) \delta=-230.26(\mathrm{td}, J=46.6,18.6 \mathrm{~Hz}) .{ }^{31} \mathrm{P}\left\{/{ }^{1} \mathrm{H}\right\} \mathrm{NMR}$ $(243 \mathrm{MHz}) \delta=15.70$ (s). Minor invertomer had: ${ }^{19} \mathrm{~F}$ NMR (565 $\mathrm{MHz}) \delta=-230.66(\mathrm{td}, J=46.8,19.2 \mathrm{~Hz}) .{ }^{31} \mathrm{P}\left\{/{ }^{1} \mathrm{H}\right\} \mathrm{NMR}(243$ $\mathrm{MHz}) \delta=15.88$ (s). HRMS (ESI) calcd for $\mathrm{C}_{8} \mathrm{H}_{15} \mathrm{FNNaO}_{5} \mathrm{P}^{+}([\mathrm{M}+$ $\mathrm{Na}^{+}$): 278.0564, found: 278.0576. Compound 22b, epimerized during reaction or purification on silica gel yielding 22a. Major invertomer had: ${ }^{31} \mathrm{P}$ NMR (162 MHz) $\delta=15.87(\mathrm{~d}, J=1.2 \mathrm{~Hz})$. ${ }^{19} \mathrm{~F}$ NMR $(377 \mathrm{MHz}) \delta=-235.11$ (tdd, $J=46.1,22.8,1.3 \mathrm{~Hz}$ ). Minor invertomer had: ${ }^{31} \mathrm{P}$ NMR (162 MHz) $\delta=16.84(\mathrm{~s}) \cdot{ }^{19} \mathrm{~F}$ NMR (377 MHz) $\delta=-233.90(\mathrm{td}, J=46.8,22.6 \mathrm{~Hz})$.

Benzyl (S)-4-((R)-(diethoxyphosphoryl)((pyridin-2-ylsulfonyl)oxy) methyl)-2,2-dimethyloxazolidine-3-carboxylate (23). Isolated with a yield $60 \%$ (Note C5) as a slightly yellow oil, mixture of two rotamers (1.5 : 1). Major rotamer had: ${ }^{1} \mathrm{H}$ NMR $(400 \mathrm{MHz}) \delta=$ 8.71 (br d, $J=4.6 \mathrm{~Hz}, 1 \mathrm{H}, \mathrm{Ar}$ ), 7.95 (d, $J=7.8 \mathrm{~Hz}, 1 \mathrm{H}, \mathrm{Ar}$ ), 7.947.85 (m, 1H, Ar), 7.56-7.49 (m, 2H, Ar), 7.43-7.34 (m, 3H, Ph), 7.36-7.31 (m, 1H, Ph), 5.73 (dd, $J=11.0,1.5 \mathrm{~Hz}, 1 \mathrm{H}, \mathrm{CHP}), 5.33-$ $5.10\left(\mathrm{~m}, 2 \mathrm{H}, \mathrm{OCH}_{2} \mathrm{Ph}\right), 4.33-4.28$ (m, 1H, CHCHP), 4.28-4.25 (m, $1 \mathrm{H}, \mathrm{OCH} \mathrm{H}), 4.16-4.02(\mathrm{~m}, 1 \mathrm{H}, \mathrm{OCH} H), 4.16-4.02(\mathrm{~m}, 2 \mathrm{H}$, $\left.\mathrm{OCH}_{2} \mathrm{CH}_{3}\right), 3.95-3.88\left(\mathrm{~m}, 2 \mathrm{H}, \mathrm{OCH}_{2} \mathrm{CH}_{3}\right), 1.47\left(\mathrm{~s}, 3 \mathrm{H}, \mathrm{C}\left(\mathrm{CH}_{3}\right)_{2}\right)$, $1.22\left(\mathrm{~s}, 3 \mathrm{H}, \mathrm{C}\left(\mathrm{CH}_{3}\right)_{2}\right), 1.19\left(\mathrm{t}, J=7.1 \mathrm{~Hz}, \mathrm{OCH}_{2} \mathrm{CH}_{3}\right), 1.18(\mathrm{t}, J=$ $\left.7.1 \mathrm{~Hz}, 3 \mathrm{H}, \mathrm{OCH}_{2} \mathrm{CH}_{3}\right) .{ }^{13} \mathrm{C} \mathrm{NMR}(151 \mathrm{MHz}) \delta=154.84(\mathrm{~s}, \mathrm{C}=\mathrm{O})$, 152.27 (s, Ar), 150.58 (s, Ar), 138.13 (s, Ar), 136.12 (s, Ph), 128.91 (s, Ph), 128.70 (s, Ph), 128.37 (s, Ph), 128.36 (s, Ph), 128.28 (s, $\mathrm{Ph}), 127.81$ (s, Ar), 123.40 (s, Ar), $95.13\left(\mathrm{~s}, C\left(\mathrm{CH}_{3}\right)_{2}\right), 75.37$ (d, $J=$ 159.0 Hz, CHP), 67.69 (s, $\mathrm{OCH}_{2} \mathrm{Ph}$ ), 63.75-63.53 (m, $\mathrm{OCH}_{2} \mathrm{CH}_{3}$ ), $63.44\left(\mathrm{~d}, J=6.6 \mathrm{~Hz}, \mathrm{OCH}_{2} \mathrm{CH}_{3}\right), 63.64\left(\mathrm{~s}, \mathrm{OCH}_{2}\right), 56.78(\mathrm{~d}, J=$ $10.7 \mathrm{~Hz}, \mathrm{CHCHP}), 24.73\left(\mathrm{~s}, \mathrm{C}\left(\mathrm{CH}_{3}\right)_{2}\right), 23.70\left(\mathrm{~s}, \mathrm{C}\left(\mathrm{CH}_{3}\right)_{2}\right), 16.43$ (d, $\left.J=5.6 \mathrm{~Hz}, \mathrm{OCH}_{2} \mathrm{CH}_{3}\right), 16.32\left(\mathrm{~d}, J=5.8 \mathrm{~Hz}, \mathrm{OCH}_{2} \mathrm{CH}_{3}\right) .{ }^{31} \mathrm{P}\left\{/{ }^{1} \mathrm{H}\right\}$ NMR $(162 \mathrm{MHz}) \delta=15.08(\mathrm{~s})$. Minor rotamer had: ${ }^{1} \mathrm{H}$ NMR $(400$ $\mathrm{MHz}) \delta=8.71$ (br d, $J=4.6 \mathrm{~Hz}, 1 \mathrm{H}, \mathrm{Ar}), 8.03(\mathrm{~d}, J=7.9 \mathrm{~Hz}, 1 \mathrm{H}$, Ar), 7.94-7.85 (m, 1H, Ar), 7.56-7.49 (m, 2H, Ar), 7.43-7.34 (m, $3 \mathrm{H}, \mathrm{Ph}$ ), 7.36-7.31 (m, 1H, Ph), 5.88 (dd, $J=11.1,1.6 \mathrm{~Hz}, 1 \mathrm{H}$, CHP), 5.33-5.10 (m, 2H, OCH $\left.\mathrm{O}_{2} \mathrm{Ph}\right), 4.41-4.36$ (m, 1H, CHCHP), 4.33-4.28 (m, 1H, OCHH), 4.16-4.02 (m, 1H, OCH H), 4.16-4.02 $\left(\mathrm{m}, 4 \mathrm{H}, 2 \times \mathrm{OCH}_{2} \mathrm{CH}_{3}\right), 1.49\left(\mathrm{~s}, 3 \mathrm{H}, \mathrm{C}\left(\mathrm{CH}_{3}\right)_{2}\right), 1.44(\mathrm{~s}, 3 \mathrm{H}$, $\left.\mathrm{C}\left(\mathrm{CH}_{3}\right)_{2}\right), 1.33-1.22\left(\mathrm{~m}, 6 \mathrm{H}, 2 \times \mathrm{OCH}_{2} \mathrm{CH}_{3}\right) .{ }^{13} \mathrm{C} \mathrm{NMR}(151 \mathrm{MHz})$ $\delta=154.65$ (s, $C=\mathrm{O}), 153.51$ (s, Ar), 150.29 (s, Ar), 138.05 (s, Ar), 136.15 (s, Ph), 128.91 (s, Ph), 128.70 (s, Ph), 128.37 (s, Ph), 128.30 (s, Ph), 128.27 (s, Ph), 128.16 (s, Ar), 123.70 (s, Ar), 94.67 (s, $\left.C\left(\mathrm{CH}_{3}\right)_{2}\right), 74.05$ (d, $\left.J=161.5 \mathrm{~Hz}, C \mathrm{HP}\right), 67.59\left(\mathrm{~s}, \mathrm{OCH}_{2} \mathrm{Ph}\right)$, $63.89\left(\mathrm{~d}, J=6.9 \mathrm{~Hz}, \mathrm{OCH}_{2} \mathrm{CH}_{3}\right), 63.75-63.53\left(\mathrm{~m}, \mathrm{OCH}_{2} \mathrm{CH}_{3}\right)$, $63.01\left(\mathrm{~s}, \mathrm{OCH}_{2}\right), 58.02(\mathrm{~d}, J=10.0 \mathrm{~Hz}, C \mathrm{HCHP}), 25.93$ (s, $\left.\mathrm{C}\left(\mathrm{CH}_{3}\right)_{2}\right), 25.43\left(\mathrm{~s}, \mathrm{C}\left(\mathrm{CH}_{3}\right)_{2}\right), 16.46\left(\mathrm{~d}, J=5.7 \mathrm{~Hz}, \mathrm{OCH}_{2} C_{3} \mathrm{H}_{3}\right.$, $16.33\left(\mathrm{~d}, J=5.7 \mathrm{~Hz}, \mathrm{OCH}_{2} C_{3}\right) .{ }^{31} \mathrm{P}\left\{/{ }^{1} \mathrm{H}\right\} \mathrm{NMR}(162 \mathrm{MHz}) \delta=$ 15.36 (s). HRMS (ESI) calcd for $\mathrm{C}_{23} \mathrm{H}_{31} \mathrm{~N}_{2} \mathrm{NaO}_{9} \mathrm{PS}^{+}\left([\mathrm{M}+\mathrm{Na}]^{+}\right)$: 565.1380, found: 565.1394.

tert-Butyl (S)-4-((R)-(diethoxyphosphoryl)((pyridin-2-ylsulfonyl) oxy)methyl)-2,2-dimethyloxazolidine-3-carboxylate (24). Isolated with a yield $47 \%$ (Note $\mathrm{C} 7$ ) as a transparent oil, mixture of two rotamers $(1: 1)$. Both rotamers had: ${ }^{1} \mathrm{H} \mathrm{NMR}(400 \mathrm{MHz}) \delta=8.74$ (br t, $J=4.8 \mathrm{~Hz}, 2 \mathrm{H}, \mathrm{Ar}$ ), 8.05 (dd, $J=7.5,4.5 \mathrm{~Hz}, 2 \mathrm{H}, \mathrm{Ar}), 7.92(\mathrm{t}$, $J=7.8 \mathrm{~Hz}, 2 \mathrm{H}, \mathrm{Ar}), 7.57-7.51(\mathrm{~m}, 2 \mathrm{H}, \mathrm{Ar}), 5.82$ (dd, $J=11.0$, $1.6 \mathrm{~Hz}, 1 \mathrm{H}, \mathrm{CHP}), 5.77$ (d, $J=11.1 \mathrm{~Hz}, 1 \mathrm{H}, \mathrm{CHP}), 4.35-4.30(\mathrm{~m}$, 1H, CHCHP), 4.28-4.23 (m, 3H, $2 \times \mathrm{OCHH}, \mathrm{CHCHP}), 4.22-3.94$ $\left(\mathrm{m}, 10 \mathrm{H}, 2 \times \mathrm{OCH}, 4 \times \mathrm{OCH}_{2} \mathrm{CH}_{3}\right), 4.11-4.03(\mathrm{~m}, 4 \mathrm{H}, 2 \times$ $\left.\mathrm{OCH}_{2} \mathrm{CH}_{3}\right), 1.58\left(\mathrm{~s}, 12 \mathrm{H}, 4 \times \mathrm{CH}_{3}\right), 1.53\left(\mathrm{~s}, 9 \mathrm{H}, 3 \times \mathrm{CH}_{3}\right), 1.47(\mathrm{~s}$, $\left.3 \mathrm{H}, \mathrm{CH}_{3}\right), 1.41\left(\mathrm{~s}, 3 \mathrm{H}, \mathrm{CH}_{3}\right), 1.33\left(\mathrm{t}, J=7.0 \mathrm{~Hz}, 3 \mathrm{H}, \mathrm{OCH}_{2} \mathrm{CH}_{3}\right)$, $1.30\left(\mathrm{t}, J=7.0 \mathrm{~Hz}, 3 \mathrm{H}, \mathrm{OCH}_{2} \mathrm{CH}_{3}\right), 1.30-1.22\left(\mathrm{~m}, 3 \mathrm{H}, \mathrm{OCH}_{2} \mathrm{CH}_{3}\right)$, $1.25\left(\mathrm{~s}, 3 \mathrm{H}, \mathrm{CH}_{3}\right), 1.22\left(\mathrm{t}, J=7.0 \mathrm{~Hz}, 3 \mathrm{H}, \mathrm{OCH}_{2} \mathrm{CH}_{3}\right) .{ }^{13} \mathrm{C} \mathrm{NMR}$ (101 MHz) $\delta=155.05(\mathrm{~s}, C=\mathrm{O}), 154.81(\mathrm{~s}, C=\mathrm{O}), 152.75(\mathrm{~s}, \mathrm{Ar})$, 151.77 (s, Ar), 150.48 (s, Ar), 150.23 (s, Ar), 138.09 (s, Ar), 137.98 (s, Ar), 127.78 (s, Ar), 127.75 (s, Ar), 123.73 (s, Ar), 123.34 (s, Ar), $94.69\left(\mathrm{~s}, C\left(\mathrm{CH}_{3}\right)_{2}\right), 94.33\left(\mathrm{~s}, C\left(\mathrm{CH}_{3}\right)_{2}\right), 81.07\left(\mathrm{~s}, C\left(\mathrm{CH}_{3}\right)_{3}\right), 81.02(\mathrm{~s}$, $\left.C\left(\mathrm{CH}_{3}\right)_{3}\right), 75.93(\mathrm{~d}, J=161.2 \mathrm{~Hz}, C \mathrm{HP}), 74.29$ (d, $J=161.4 \mathrm{~Hz}$, $C \mathrm{HP}), 63.84$ (d, $\left.J=7.4 \mathrm{~Hz}, \mathrm{OCH}_{2} \mathrm{CH}_{3}\right), 63.61$ (d, $J=6.7 \mathrm{~Hz}$, $\left.\mathrm{OCH}_{2} \mathrm{CH}_{3}\right), 63.54-63.23\left(\mathrm{~m}, 2 \times \mathrm{OCH}_{2} \mathrm{CH}_{3}\right), 63.35\left(\mathrm{~s}, \mathrm{OCH}_{2}\right)$, $62.82\left(\mathrm{~s}, \mathrm{OCH}_{2}\right), 57.61$ (d, $\left.J=10.2 \mathrm{~Hz}, C \mathrm{HCHP}\right), 56.98$ (d, $J=$ $10.9 \mathrm{~Hz}, C \mathrm{HCHP}), 29.83\left(\mathrm{~s}, \mathrm{CH}_{3}\right), 28.55\left(\mathrm{~s}, 9 \times \mathrm{CH}_{3}\right), 16.48$ (d, $J=$ $\left.5.6 \mathrm{~Hz}, 4 \times \mathrm{OCH}_{2} \mathrm{CH}_{3}\right) .{ }^{31} \mathrm{P} \mathrm{NMR}(162 \mathrm{MHz}) \delta=15.86(\mathrm{~s}), 15.62$ (s). HRMS (ESI) calcd for $\mathrm{C}_{20} \mathrm{H}_{34} \mathrm{~N}_{2} \mathrm{O}_{9} \mathrm{PS}^{+}\left([\mathrm{M}+\mathrm{H}]^{+}\right)$: 509.1717, found: 509.1711 .

Diethyl ((4S,5S)-3-benzyl-4-(fluoromethyl)-2,2-dimethyloxazolidin-5$y l)$ phosphonate (26a) and diethyl ((4S,5R)-3-benzyl-4-(fluoromethyl)2,2-dimethyloxazolidin-5-yl)phosphonate (26b). Isolated with a yield 58\% (Note A9) as transparent oil. Major diastereoisomer 26a (major invertomer) had: ${ }^{1} \mathrm{H}$ NMR (400 MHz) $\delta=7.40-7.37(\mathrm{~m}$, 2H, Ph), 7.33-7.28 (m, 2H, Ph), 7.26-7.21 (m, 1H, Ph), 4.25 (dd, J $=47.2,4.0 \mathrm{~Hz}, 1 \mathrm{H}, \mathrm{CHHF}), 4.23(\mathrm{~d}, J=47.4,4.0 \mathrm{~Hz}, 1 \mathrm{H}, \mathrm{CH} H \mathrm{~F})$, 4.29-4.14 (m, $\left.4 \mathrm{H}, 2 \times \mathrm{OCH}_{2} \mathrm{CH}_{3}\right), 4.14(\mathrm{dd}, J=8.7,2.3 \mathrm{~Hz}, 1 \mathrm{H}$, CHP), 3.94 (d, $J=14.6 \mathrm{~Hz}, 1 \mathrm{H}, \mathrm{CHHPh}), 3.74$ (d, $J=14.6 \mathrm{~Hz}, 1 \mathrm{H}$, CHHPh), 3.62-3.46 (m, 1H, CHCHP), 1.40 (s, 3H, $\mathrm{CH}_{3}$ ), 1.40- 
$1.30\left(\mathrm{~m}, 6 \mathrm{H}, 2 \times \mathrm{OCH}_{2} \mathrm{CH}_{3}\right), 1.29\left(\mathrm{~s}, 3 \mathrm{H}, \mathrm{CH}_{3}\right) .{ }^{13} \mathrm{C} \mathrm{NMR}(101$ $\mathrm{MHz}) \delta=139.88,128.41,128.20,127.24(4 \times \mathrm{s}, \mathrm{Ph}), 98.68(\mathrm{~d}, J=$ $\left.6.6 \mathrm{~Hz}, C\left(\mathrm{CH}_{3}\right)_{2}\right), 82.05$ (dd, $J=174.6,4.4 \mathrm{~Hz}, \mathrm{CH}_{2} \mathrm{~F}$ ), 71.09 (dd, $J$ $=172.9,6.1 \mathrm{~Hz}, C \mathrm{HP}), 64.18(\mathrm{dd}, J=19.7,3.5 \mathrm{~Hz}, \mathrm{NCH}), 63.17$ (d, $J=6.8 \mathrm{~Hz}, \mathrm{OCH}_{2} \mathrm{CH}_{3}$ ), $62.76\left(\mathrm{~d}, J=6.9 \mathrm{~Hz}, \mathrm{OCH}_{2} \mathrm{CH}_{3}\right), 52.95$ $\left(\mathrm{CH}_{2} \mathrm{Ph}\right), 28.17\left(\mathrm{~s}, \mathrm{CH}_{3}\right), 22.84\left(\mathrm{~s}, \mathrm{CH}_{3}\right), 16.62(\mathrm{~d}, J=5.7 \mathrm{~Hz}, 2 \times$ $\left.\mathrm{OCH}_{2} \mathrm{CH}_{3}\right) .{ }^{19} \mathrm{~F}$ NMR $(376 \mathrm{MHz}) \delta=-227.50(\mathrm{td}, J=47.5,22.2$ $\mathrm{Hz}) .{ }^{31} \mathrm{P}\left\{/{ }^{1} \mathrm{H}\right\}$ NMR (162 MHz) $\delta=21.56(\mathrm{~s})$. Minor invertomer 26a (observed in a crude reaction mixture) had: ${ }^{19} \mathrm{~F}$ NMR (376 MHz) $\delta=-227.50(\mathrm{td}, J=47.5,22.2 \mathrm{~Hz}) .{ }^{31} \mathrm{P}\left\{/{ }^{1} \mathrm{H}\right\} \mathrm{NMR}(162$ $\mathrm{MHz}) \delta=21.56(\mathrm{~s})$. Minor diastereoisomer 26b was observed in a crude reaction mixture. Major inwertomer had: ${ }^{19}$ F NMR (565 MHz) $\delta=-230.84(\mathrm{td}, J=47.1,27.4 \mathrm{~Hz}) .{ }^{31} \mathrm{P}$ NMR $(243 \mathrm{MHz})$ $\delta=18.90$ (s). Minor invertomer had: ${ }^{19} \mathrm{~F}$ NMR (565 MHz) $\delta=$ -229.67 (td, $J=47.3,28.1 \mathrm{~Hz}) .{ }^{31} \mathrm{P}\left\{/{ }^{1} \mathrm{H}\right\} \operatorname{NMR}(162 \mathrm{MHz}) \delta=$ 20.09 (s). HRMS (ESI) calcd for $\mathrm{C}_{17} \mathrm{H}_{27} \mathrm{FNNaO}_{4} \mathrm{P}^{+}\left([\mathrm{M}+\mathrm{Na}]^{+}\right)$: 382.1557, found: 382.1554.

2. Procedure for $\boldsymbol{N}$-Boc deprotection. Preparation of diethyl $(2 S, 3 S)$-3-fluoropiperidin-2-ylphosphonate (8). Treatment of 5 with trifluoroacetic acid $\left(0{ }^{\circ} \mathrm{C}, 3 \mathrm{~h}\right)$ gave after evaporating and column chromatography $\left(\mathrm{CHCl}_{3} / \mathrm{MeOH}, 95: 5\right)$ compound 8 as transparent oil (32 mg, 73\%): ${ }^{1} \mathrm{H}$ NMR $(600 \mathrm{MHz}) \delta=4.62(\mathrm{dqd}$, $J=48.0,8.3,4.4 \mathrm{~Hz}, 1 \mathrm{H}, \mathrm{CHF}), 4.17\left(" \mathrm{pd}^{\prime \prime}, J=7.1,2.2 \mathrm{~Hz}, 4 \mathrm{H}, 2\right.$ $\left.\times \mathrm{OCH}_{2} \mathrm{CH}_{3}\right), 3.02(\mathrm{dt}, J=11.7,3.5 \mathrm{~Hz}, 1 \mathrm{H}, \mathrm{NCHH}), 2.97$ (ddd, $J$ $=10.4,8.5,5.4 \mathrm{~Hz}, 1 \mathrm{H}, \mathrm{CHP}), 2.50(\mathrm{t}, J=11.2 \mathrm{~Hz}, 1 \mathrm{H}, \mathrm{NCH} H)$, 2.26-2.18 (m, 1H, CHHCHF), 1.99 (br s, 1H, NH), 1.74 (tt, $J=7.0$, $\left.3.9 \mathrm{~Hz}, 1 \mathrm{H}, \mathrm{NCH}_{2} \mathrm{CHH}\right), 1.60-1.48\left(\mathrm{~m}, 2 \mathrm{H}, \mathrm{CH} H \mathrm{CHF}, \mathrm{NCH}_{2}-\right.$ $\mathrm{CH} H$ ), $1.33\left(\mathrm{t}, J=7.0 \mathrm{~Hz}, 3 \mathrm{H}, \mathrm{OCH}_{2} \mathrm{CH}_{3}\right), 1.32(\mathrm{t}, J=7.1 \mathrm{~Hz}, 3 \mathrm{H}$, $\left.\mathrm{OCH}_{2} \mathrm{CH}_{3}\right) .{ }^{13} \mathrm{C} \mathrm{NMR}(151 \mathrm{MHz}) \delta=88.28(\mathrm{dd}, J=177.3,3.7 \mathrm{~Hz}$, $C \mathrm{HF}$ ), 62.76 (d, $\left.J=6.7 \mathrm{~Hz}, \mathrm{OCH}_{2} \mathrm{CH}_{3}\right), 62.59$ (d, $J=6.7 \mathrm{~Hz}$, $\mathrm{OCH}_{2} \mathrm{CH}_{3}$ ), 58.09 (dd, $J=156.6,23.2 \mathrm{~Hz}, C \mathrm{HP}$ ), 45.62 (d, $J=$ $13.8 \mathrm{~Hz}, \mathrm{NCH}_{2}$ ), 31.12 (dd, $J=19.0,11.0 \mathrm{~Hz}, \mathrm{CH}_{2} \mathrm{CHF}$ ), 24.12 (d, $\left.J=9.3 \mathrm{~Hz}, \mathrm{NCH}_{2} \mathrm{CH}_{2}\right), 16.58\left(\mathrm{~d}, J=5.7 \mathrm{~Hz}, 2 \times \mathrm{OCH}_{2} \mathrm{CH}_{3}\right) .{ }^{19} \mathrm{~F}$ NMR (565 MHz) $\delta=-176.49$ to $-176.61(\mathrm{~m}) .{ }^{31} \mathrm{P}\left\{/{ }^{1} \mathrm{H}\right\}$ NMR $(243 \mathrm{MHz}) \delta=23.79(\mathrm{~d}, J=6.0 \mathrm{~Hz})$. HRMS (ESI) calcd for $\mathrm{C}_{9} \mathrm{H}_{20} \mathrm{FNO}_{3} \mathrm{P}^{+}\left([\mathrm{M}+\mathrm{H}]^{+}\right): 240.1159$, found: 240.1148 .

3. Procedure for preparation of diethyl $(2 S, 3 S)$-3-acetoxymethyl-1-(tert-butoxycarbonyl) aziridin-2-yl-2-phosphonate (20). Reaction of 19 (56 mg, $0.18 \mathrm{mmol})$ with $\mathrm{Ac}_{2} \mathrm{O}(86 \mu \mathrm{L}$, $92 \mathrm{mg}, 0.9 \mathrm{mmol})$ and $\mathrm{K}_{2} \mathrm{CO}_{3}(50 \mathrm{mg}, 0.36 \mathrm{mmol})$ in anhydrous ethyl acetate (RT, $2 \mathrm{~d}$ ) gave compound $\mathbf{2 0}$ as a transparent oil with a yield $82 \%(52 \mathrm{mg})$ as a rotamers mixture (1.1 : 1). Major rotamer had: ${ }^{1} \mathrm{H}$ NMR $(400 \mathrm{MHz}) \delta=4.31(\mathrm{dd}, J=12.1,4.3 \mathrm{~Hz}$, $1 \mathrm{H}, \mathrm{OCH}$ ), 4.23-4.09 (m, 5H, OCH H, $2 \times \mathrm{OCH}_{2} \mathrm{CH}_{3}$ ), 3.18-3.12 (m, 1H, CHCHP), 2.62 (dd, $J=18.4,3.2 \mathrm{~Hz}, 1 \mathrm{H}, \mathrm{CHP}), 2.18$ (s, $\left.3 \mathrm{H}, \mathrm{CH}_{3}\right), 1.45\left(\mathrm{~s}, 9 \mathrm{H}, \mathrm{C}\left(\mathrm{CH}_{3}\right)_{3}\right), 1.33(\mathrm{t}, J=7.1 \mathrm{~Hz}, 6 \mathrm{H}, 2 \times$ $\left.\mathrm{OCH}_{2} \mathrm{CH}_{3}\right) .{ }^{13} \mathrm{C} \mathrm{NMR}(101 \mathrm{MHz}) \delta=179.19(\mathrm{~d}, J=6.0 \mathrm{~Hz}, C=\mathrm{O})$, $152.90(\mathrm{~s}, C=\mathrm{O}), 83.06\left(\mathrm{~s}, C\left(\mathrm{CH}_{3}\right)_{3}\right), 64.63\left(\mathrm{~s}, \mathrm{OCH}_{2}\right), 62.90(\mathrm{~d}, J=$ $\left.6.2 \mathrm{~Hz}, \mathrm{OCH}_{2} \mathrm{CH}_{3}\right), 62.78\left(\mathrm{~d}, J=6.0 \mathrm{~Hz}, \mathrm{OCH}_{2} \mathrm{CH}_{3}\right), 38.14(\mathrm{~d}, J=$ $2.6 \mathrm{~Hz}, \mathrm{CHCHP}), 32.97$ (d, $J=195.6 \mathrm{~Hz}, \mathrm{CHP}), 27.78\left(\mathrm{~s}, \mathrm{C}\left(\mathrm{CH}_{3}\right)_{3}\right)$, $23.80\left(\mathrm{~s}, \mathrm{CH}_{3}\right), 16.56$ (d, $\left.J=5.6 \mathrm{~Hz}, \mathrm{OCH}_{2} \mathrm{CH}_{3}\right), 16.52$ (d, $J=$ $\left.6.1 \mathrm{~Hz}, \mathrm{OCH}_{2} \mathrm{CH}_{3}\right) .{ }^{31} \mathrm{P}\left\{/{ }^{1} \mathrm{H}\right\}$ NMR $(162 \mathrm{MHz}) \delta=18.33(\mathrm{~s})$. Minor rotamer had: ${ }^{1} \mathrm{H}$ NMR $(400 \mathrm{MHz}) \delta=4.27$ (dd, $J=4.3$, $\left.0.9 \mathrm{~Hz}, 2 \mathrm{H}, \mathrm{OCH}_{2}\right), 4.23-4.09\left(\mathrm{~m}, 4 \mathrm{H}, 2 \times \mathrm{OCH}_{2} \mathrm{CH}_{3}\right), 3.03$ (dq, $J$ $=7.9,4.1 \mathrm{~Hz}, 1 \mathrm{H}, \mathrm{CHCHP}), 2.54(\mathrm{dd}, J=17.8,3.5 \mathrm{~Hz}, 1 \mathrm{H}, \mathrm{CHP})$, $2.04\left(\mathrm{~s}, 3 \mathrm{H}, \mathrm{CH}_{3}\right), 1.46\left(\mathrm{~s}, 9 \mathrm{H}, \mathrm{C}\left(\mathrm{CH}_{3}\right)_{3}\right), 1.34(\mathrm{t}, J=6.7 \mathrm{~Hz}, 6 \mathrm{H}, 2$ $\left.\times \mathrm{OCH}_{2} \mathrm{CH}_{3}\right) \cdot{ }^{13} \mathrm{C} \mathrm{NMR}(101 \mathrm{MHz}) \delta=170.19(\mathrm{~s}, \mathrm{C}=\mathrm{O}), 158.50$ (d, $J=7.6 \mathrm{~Hz}, C=\mathrm{O}), 82.47\left(\mathrm{~s}, C\left(\mathrm{CH}_{3}\right)_{3}\right), 63.48(\mathrm{~d}, J=6.3 \mathrm{~Hz}$, $\mathrm{OCH}_{2} \mathrm{CH}_{3}$ ), 63.32 (d, $\left.J=6.2 \mathrm{~Hz}, \mathrm{OCH}_{2} \mathrm{CH}_{3}\right), 61.57\left(\mathrm{~s}, \mathrm{OCH}_{2}\right)$, 38.37 (d, $J=2.7 \mathrm{~Hz}, C \mathrm{HCHP}$ ), 32.79 (d, $J=197.8 \mathrm{~Hz}, C H \mathrm{HP}), 27.97$ (s, $\left.\mathrm{C}\left(\mathrm{CH}_{3}\right)_{3}\right), 20.82\left(\mathrm{~s}, \mathrm{CH}_{3}\right), 16.56$ (d, $\left.J=5.6 \mathrm{~Hz}, \mathrm{OCH}_{2} \mathrm{CH}_{3}\right)$, $16.52\left(\mathrm{~d}, J=6.1 \mathrm{~Hz}, \mathrm{OCH}_{2} \mathrm{CH}_{3}\right) .{ }^{31} \mathrm{P}\left\{/{ }^{1} \mathrm{H}\right\} \mathrm{NMR}(162 \mathrm{MHz}) \delta=$ $18.63(\mathrm{~s})$.

\section{Conflicts of interest}

There are no conflicts to declare.

\section{Acknowledgements}

We thank to National Science Centre (grant HARMONIA/2017/ 26/M/ST5/00437) for financial support.

\section{References}

1 (a) Aminophosphonic and Aminophosphinic Acids, ed. V. P. Kukhar and H. R. Hudson, John Wiley \& Sons Ltd, Chichester, 2000; For some review see; $(b)$ P. Kafarski and B. Lejczak, Curr. Med. Chem.: Anti-Cancer Agents, 2001, 1, 301-312; (c) J. Grembecka and P. Kafarski, Mini-Rev. Med. Chem., 2001, 1, 133-144; (d) M. Ordóñez, H. Rojas-Cabrera and C. Cativiela, Tetrahedron, 2009, 65, 17-49; (e) S. Van der Jeught and Ch. S. Stevens, Chem. Rev., 2009, 109, 26722702; (f) F. Orsini, G. Sello and M. Sisti, Curr. Med. Chem., 2010, 17, 264-289; (g) E. D. Naydenova, P. T. Todorov and K. D. Troev, Amino Acids, 2010, 38, 23-30; $(h)$ M. Ordóñez, J. L. Viveros-Ceballos, C. Cativiela and F. J. Sayago, Tetrahedron, 2015, 71, 1745-1784.

2 G. P. Horsman and D. L. Zechel, Chem. Rev., 2017, 117, 57045783.

3 (a) B. Boduszek, J. Oleksyszyn, C.-M. Kam, J. Selzler, R. E. Smith and J. C. Powers, J. Med. Chem., 1994, 37, 3969-3976; (b) A. M. Lambeir, M. Borloo, I. De Meester, A. Belyaev, K. Augustyns, D. Hendriks, S. Scharpé and A. Haemers, Biochim. Biophys. Acta, 1996, 1290, 76-82.

4 Y. Surh, R. P. Spencer, L. A. Spitznagle, F. Hosain and B. Lejczak, J. Nucl. Med., 1986, 27, 847-849.

5 (a) A. R. Katritzky, X.-L. Cui, B. Yang and P. J. Steel, J. Org. Chem., 1999, 64, 1979-1985; (b) P. Dinér and M. Amedjkouh, Org. Biomol. Chem., 2006, 4, 2091-2096; (c) Q. Tao, G. Tang, K. Lin and Y.-F. Zhao, Chirality, 2008, 20, 833-838; (d) S. Hirata, M. Kuriyama and O. Onomura, Tetrahedron, 2011, 67, 9411-9416; (e) T. Ma, X. Fu, C. W. Kee, L. Zong, Y. Pan, K.-W. Huang and C.-H. Tan, J. Am. Chem. Soc., 2011, 133, 2828-2831; (f) F. Wuggenig, A. Schweifer, K. Mereiter and F. Hammerschmidt, Eur. J. Org. Chem., 2011, 1870-1879; (g) B. Kaboudin, J.-Y. Kato, H. Aoyama and T. Yokomatsu, Tetrahedron: Asymmetry, 2013, 24, 1562-1566; (h) M. H. Kudzin, Z. H. Kudzin and J. Drabowicz, ARKIVOC, 2011, vi, 227-269.

6 (a) G. T. Anderson, M. D. Alexander, S. D. Taylor, D. B. Smithrud, S. J. Benkovic and S. M. Weinreb, J. Org. Chem., 1996, 61, 125-132; (b) T. Widianti, Y. Hiraga, S. Kojima and M. Abe, Tetrahedron: Asymmetry, 2010, 21, 
1861-1868; (c) O. O. Kolodyazhnaya, A. O. Kolodyazhnaya and O. I. Kolodyazhnyi, Russ. J. Gen. Chem., 2014, 84, 169170.

7 (a) A. B. Smith, III, K. M. Yager, B. W. Phillips and C. M. Taylor, Org. Synth., 1998, 75, 19-29; (b) F. Hammerschmidt, W. Lindner, F. Wuggenig and E. Zarbl, Tetrahedron: Asymmetry, 2000, 11, 2955-2964; (c) E. K. Dolence, G. Mayer and B. D. Kelly, Tetrahedron: Asymmetry, 2005, 16, 1583-1594.

8 (a) J. Nieschalk, A. S. Batsanov, D. O'Hagan and J. A. K. Howard, Tetrahedron, 1996, 52, 165-176; (b) D. B. Berkowitz, M. Bose, T. J. Pfannenstiel and T. Doukov, J. Org. Chem., 2000, 65, 4498-4508; (c) D. O'Hagan and H. S. Rzepa, Chem. Commun., 1997, 645-652; (d) S. M. Forget, D. Bhattasali, V. C. Hart, T. S. Cameron, R. T. Syvitskiad and D. L. Jakeman, Chem. Sci., 2012, 3, 1866-1878.

9 For some review see: (a) V. D. Romanenko and V. P. Kukhar, Chem. Rev., 2006, 106, 3868-3935; (b) K. V. Turcheniuk, V. P. Kukhar, G.-V. Röschenthaler, J. L. Aceña, V. A. Soloshonok and A. E. Sorochinsky, RSC Adv., 2013, 3, 6693-6716; (c) M. Rapp, T. Cytlak, M. Z. Szewczyk and H. Koroniak, Curr. Green Chem., 2015, 2, 237-253; (d) T. Cytlak, M. Kaźmierczak, M. Skibińska and H. Koroniak, Phosphorus, Sulfur Silicon Relat. Elem., 2017, 192, 602-620.

10 (a) J. T. Welch, Tetrahedron, 1987, 43, 3123-3197; (b) J. Mann, Chem. Soc. Rev., 1987, 16, 381-436; (c) J.-P. Bégué and D. Bonnet-Delpon, Bioorganic and Medicinal Chemistry of Fluorine, Wiley \& Sons: New Jersey, 2008; (d) S. Purser, P. R. Moore, S. Swallow and V. Gouverneur, Chem. Soc. Rev., 2008, 37, 320-330; (e) D. O'Hagan, Chem. Soc. Rev., 2008, 37, 308-319.

11 For some examples see: (a) G. A. Flynn, D. W. Beight, E. H. W. Bohme and B. W. Metcalf, Tetrahedron Lett., 1985, 26, 285-288; (b) P. Van der Veken, K. Senten, I. Kertèsz, A. Haemers and K. Augustyns, Tetrahedron Lett., 2003, 44, 969-972; (c) P. Cui, W. F. McCalmont, J. L. Tomsig, K. R. Lynch and T. L. Macdonald, Bioorg. Med. Chem., 2008, 16, 2212-2225; (d) J. E. East, A. J. Kennedy, J. L. Tomsig, A. R. De Leon, K. R. Lynch and T. L. Macdonald, Bioorg. Med. Chem. Lett., 2010, 20, 71327136.

12 (a) A. H. Fauq, $N, N$-diethylaminosulfur trifluoride, in Encyclopedia of Reagents for Organic Synthesis, ed. L. Paquette, John Wiley \& Sons, New York, 2004; (b) W. J. Middleton, J. Org. Chem., 1975, 40, 574-578.

13 (a) G. S. Lal, G. P. Pez, R. J. Pesaresi and F. M. Prozonic, Chem. Commun., 1999, 215-216; (b) G. S. Lal, G. P. Pez, R. J. Pesaresi, F. M. Prozonic and H. Cheng, J. Org. Chem., 1999, 64, 7048-7054.

14 (a) M. K. Nielsen, C. R. Ugaz, W. Li and A. G. Doyle, J. Am. Chem. Soc., 2015, 137, 9571-9574; (b) M. K. Nielsen, D. T. Ahneman, O. Riera and A. G. Doyle, J. Am. Chem. Soc., 2018, 140, 5004-5008.

15 (a) S. B. D. Jarvis and A. B. Charette, Org. Lett., 2011, 13, 3830-3833; (b) C. Ye and J. M. Shreeve, J. Fluorine Chem., 2004, 125, 1869-1872; (c) T. Rosen, D. T. W. Chu,
I. M. Lico, P. B. Fernandes, K. Marsh, L. Shen, V. G. Cepa and A. G. Pernet, J. Med. Chem., 1988, 31, 1598-1611; (d) I. Déchamps, D. Gomez Pardo and J. Cossy, Synlett, 2007, 2, 263-267; (e) I. Déchamps, D. Gomez Pardo and J. Cossy, Eur. J. Org. Chem., 2007, 4224-4234; (f) P. K. Mykhailiuk, S. V. Shishkina, O. V. Shishkin, O. A. Zaporozhec and I. V. Komarov, Tetrahedron, 2011, 67, 3091-3097; $(g)$ H. Ferret, I. Déchamps, D. Gomez Pardo, L. Van Hijfte and J. Cossy, ARKIVOC, 2010, 8, 126-159; (h) T.-X. Métro, B. Duthion, D. Gomez Pardo and J. Cossy, Chem. Soc. Rev., 2010, 39, 89-102.

16 M. Kaźmierczak and H. Koroniak, J. Fluorine Chem., 2012, 139, 23-27.

17 M. Kaźmierczak, M. Kubicki and H. Koroniak, Eur. J. Org. Chem., DOI: 10.1002/ejoc.201800631.

18 K. Radwan-Olszewska, F. Palacios and P. Kafarski, J. Org. Chem., 2011, 76, 1170-1173.

19 M. Kaźmierczak, M. Kubicki and H. Koroniak, J. Fluorine Chem., 2014, 167, 128-134.

20 F. Palacios, A. M. Ochoa de Retana, J. Oyarzabal, S. Pascual and G. F. de Trocóniz, J. Org. Chem., 2008, 73, 4568-4574.

21 M. Rapp, P. Mrowiec and H. Koroniak, Phosphorus, Sulfur Silicon Relat. Elem., 2017, 192, 745-751.

22 M. Rapp, M. Bilska and H. Koroniak, J. Fluorine Chem., 2011, 132, 1232-1240.

23 W. R. Dolbier Jr, Guide to Fluorine NMR for Organic Chemists, Wiley Interscience, 2009.

24 C. Zhang, Z. Li, L. Zhu, L. Yu, Z. Wang and C. Li, J. Am. Chem. Soc., 2013, 135, 14082-14085.

25 T. Wu, G. Yin and G. Liu, J. Am. Chem. Soc., 2009, 131, 1635416355.

26 (a) C. R. S. Briggs, D. O'Hagan, J. A. K. Howard and D. S. Yufit, J. Fluorine Chem., 2003, 119, 9-13; (b) D. O'Hagan, C. Bilton, J. A. K. Howard, L. Knight and D. J. Tozer, J. Chem. Soc., Perkin Trans. 2, 2000, 605-607.

27 (a) H. Zhao and A. Thurkauf, Synlett, 1999, 8, 1280-1282; (b) S. De Jonghe, I. Van Overmeire, S. Van Calenbergh, C. Hendrix, R. Busson, D. De Keukeleire and P. Herdewijn, Eur. J. Org. Chem., 2000, 3177-3183.

28 (a) D. V. Patel, K. Rielly-Gauvin and D. E. Ryono, Tetrahedron Lett., 1990, 31, 5587-5590; (b) D. V. Patel, K. Rielly-Gauvin, D. E. Ryono, C. A. Free, W. L. Rogers, S. A. Smith, J. M. DeForrest, R. S. Oehl and E. W. Petrillo Jr, J. Med. Chem., 1995, 38, 4557-4569.

29 D. Willén, D. Bengtsson, S. Clementson, E. Tykesson, S. Manner and U. Ellervik, J. Org. Chem., 2018, 83, 12591277.

30 Phosphorus-31 NMR. Principles and Applications, ed. D. G. Gorenstein, Academic Press. Inc., Orlando, 1984.

31 A. De La Cruz, A. He, A. Thanavaro, B. Yan, C. D. Spilling and N. P. Rath, J. Organomet. Chem., 2005, 690, 2577-2592.

32 A. E. Wróblewski and J. Drozd, Tetrahedron: Asymmetry, 2011, 22, 200-206.

33 G. V. De Lucca, J. Org. Chem., 1998, 63, 4755-4766.

34 R. H. Furneaux, G. J. Gainsford, J. M. Mason and P. C. Tyler, Tetrahedron, 1994, 50, 2131-2160. 
35 C. Carpentier, R. Godbout, F. Otis and N. Voyer, Tetrahedron Lett., 2015, 56, 1244-1246.

36 T. Cytlak, M. Skibińska, P. Kaczmarek, M. Kaźmierczak, M. Rapp, M. Kubicki and H. Koroniak, $R S C A d v$., 2018, 8, 11957-11974.
37 A. E. Wróblewski and K. B. Balcerzak, Tetrahedron: Asymmetry, 2001, 12, 427-431. 